\title{
New approach to monitor transboundary particulate pollution over Northeast Asia
}

\author{
M. E. Park ${ }^{1}$, C. H. Song ${ }^{1}$, R. S. Park ${ }^{1}$, J. Lee ${ }^{2,3,4}$, J. Kim ${ }^{2}$, S. Lee ${ }^{1}$, J.-H. Woo ${ }^{5}$, G. R. Carmichael ${ }^{6}$, T. F. Eck ${ }^{4,7}$, \\ B. N. Holben ${ }^{4}$, S.-S. Lee ${ }^{8}$, C. K. Song ${ }^{9}$, and Y. D. Hong ${ }^{9}$ \\ ${ }^{1}$ School of Environmental Science and Engineering, Gwangju Institute of Science and Technology (GIST), Gwangju, \\ 500-712, Korea \\ ${ }^{2}$ Department of Atmospheric Sciences, Yonsei University, Seoul, 120-749, Korea \\ ${ }^{3}$ Earth System Science Interdisciplinary Center, University of Maryland, College Park, Maryland, USA \\ ${ }^{4}$ Laboratory for Terrestrial Physics, Goddard Space Flight Center, National Aeronautics and Space Administration (NASA), \\ Greenbelt, Maryland, USA \\ ${ }^{5}$ Department of Advanced Technology Fusion, Konkuk University, Seoul, 143-701, Korea \\ ${ }^{6}$ Department of Chemical and Biochemical Engineering, University of Iowa, Iowa City, Iowa, USA \\ ${ }^{7}$ Universities Space Research Association, Columbia, Maryland, USA \\ ${ }^{8}$ National Institute of Meteorological Research, Seoul, 156-720, Korea \\ ${ }^{9}$ Air Quality Research Department, National Institute of Environmental Research (NIER), Incheon, 404-170, Korea
}

Correspondence to: C. H. Song (chsong@gist.ac.kr)

Received: 29 March 2013 - Published in Atmos. Chem. Phys. Discuss.: 14 June 2013

Revised: 29 November 2013 - Accepted: 3 December 2013 - Published: 22 January 2014

\begin{abstract}
A new approach to more accurately monitor and evaluate transboundary particulate matter (PM) pollution is introduced based on aerosol optical products from Korea's Geostationary Ocean Color Imager (GOCI). The area studied is Northeast Asia (including eastern parts of China, the Korean peninsula and Japan), where GOCI has been monitoring since June 2010. The hourly multi-spectral aerosol optical data that were retrieved from GOCI sensor onboard geostationary satellite COMS (Communication, Ocean, and Meteorology Satellite) through the Yonsei aerosol retrieval algorithm were first presented and used in this study. The GOCI-retrieved aerosol optical data are integrated with estimated aerosol distributions from US EPA Models-3/CMAQ (Community Multi-scale Air Quality) v4.5.1 model simulations via data assimilation technique, thereby making the aerosol data spatially continuous and available even for cloud contamination cells. The assimilated aerosol optical data are utilized to provide quantitative estimates of transboundary PM pollution from China to the Korean peninsula and Japan. For the period of 1 April to 31 May, 2011 this analysis yields estimates that $\mathrm{AOD}$ as a proxy for $\mathrm{PM}_{2.5}$ or $\mathrm{PM}_{10}$ during long-range transport events increased by $117-265 \%$ com-
\end{abstract}

pared to background average AOD (aerosol optical depth) at the four AERONET sites in Korea, and average AOD increases of $121 \%$ were found when averaged over the entire Korean peninsula. This paper demonstrates that the use of multi-spectral AOD retrievals from geostationary satellites can improve estimates of transboundary PM pollution. Such data will become more widely available later this decade when new sensors such as the GEMS (Geostationary Environment Monitoring Spectrometer) and GOCI-2 are scheduled to be launched.

\section{Introduction}

Transboundary air pollution is an important issue in Asia (Arndt et al., 1998; Holloway et al., 2002; Yamaji et al., 2012). In particular, the long-range transport (LRT) of air pollutants from China (source) to the Korean peninsula and Japan (receptors) due to persistent westerlies over Northeast Asia has been a central issue in this region (Arndt et al., 1998; Song and Carmichael, 2001; Yamaji et al., 2012). Transboundary air pollution is a serious issue not only in 
Asia, but also in Europe and North America, causing a number of different international problems such as acid precipitation, rising levels of hemispheric ground-level ozone, and regional visibility impairment (Levy II and Moxim, 1987; Brankov et al., 2003; Holloway et al., 2003; Tulet et al., 2003; Park et al., 2004; Wang et al., 2009). To manage transboundary air pollution between countries, the Convention on Long-Range Transboundary Air Pollution (CLRTAP) under the UNECE (United Nations Economic Commission for Europe) was launched to lessen air pollution through the LRT in 1979 (http://www.unece.org/env/lrtap/lrtap_h1.html). The EMEP (European Monitoring and Evaluation Programme) is a scientific effort established to support the CLRTAP.

Quantitative evaluation of transboundary air pollution remains a difficult task and currently cannot be done based on observations alone due to a lack of explicit source signatures and lack of an appropriate observation system (Malcolm et al., 2000; Brankov et al., 2003; Tulet et al., 2003; Park et al., 2004; Schaub et al., 2005; Wang et al., 2009). Most current evaluations of transboundary transport of pollutants are based on chemistry-transport model (CTM) simulations (Levy II and Moxim, 1987; Arndt et al., 1998; Holloway et al., 2002; Wang et al., 2009; Yamaji et al., 2012). By controlling the emissions from a source country (e.g., China) in the CTM simulations, transboundary air pollution from the source country to receptor regions has been evaluated. However, these model-based evaluations have significant limitations because of the large uncertainties in the emission rates of the air pollutants from the source country (or region), the highly nonlinear nature of atmospheric chemistry, and uncertainties related to the CTM and meteorological models (MM). For example, both atmospheric secondary particle formation and primary particle (e.g., mineral dust) generation/transport are difficult to correctly simulate (Song and Carmichael, 2001; Song et al., 2005; Volkamer et al., 2006; Robinson et al., 2007). These uncertainties are a main reason for disagreement in source and receptor estimates made by different countries, which has led to distrust of the outcomes of model-based assessments.

Current efforts to reduce the uncertainty in estimates of long-range transport of pollutants by integrating models and observations through data assimilation are limited by our current observational systems. Surface-based observations are too sparse to constrain the system, while current satellites are unable to retrieve aerosol concentrations. Instead, satellite retrievals of AOD are used to help constrain modeled AOD and the modeled relationship between AOD and surface-level PM (particulate matter) can then be used to estimate surface-level PM concentrations (Wang and Christopher, 2003; Liu et al., 2005; van Donkelaar et al., 2006; Schaap et al., 2009; Tsai et al., 2011). This approach is currently limited by the fact that AOD from polar-orbiting satellites produce retrievals only once per day (Kaufman et al., 1997; Diner et al., 2001) and current geostationary satellites lack "multi-spectral" aerosol data (Knapp et al., 2002; Wang et al., 2003). For example, the USA GOES series (GOES 8, 13), the Japanese GMS and MTSAT, and European SEVIRI have been meteorological sensors with only one to two visible channels. The history of GEO satellite sensors for the retrieval of the aerosol optical properties is summarized in Table 1.

This situation is changing as new geostationary satellite based sensors are becoming available and will be expanded by upcoming planned missions. The first hourly multi-spectral aerosol data observed from a geostationary satellite sensor, GOCI (Geostationary Ocean Color Imager) is used in this paper to demonstrate how this new information can be used to improve our estimates of LRT of pollutants. Specifically, the level 1 radiance data from GOCI, onboard COMS (Communication, Ocean, and Meteorology Satellite), is converted into level 2 AOD products via the "Yonsei aerosol retrieval algorithm" (the details of the algorithm will be discussed in the Methods section) (Lee et al., 2010). COMS/GOCI was launched in June 2010, and the COMS/GOCI data center began to release radiance data in April 2011, after an initial operation test (IOT) period. This satellite sensor was designed for monitoring ocean colors around the Korean peninsula, but it can also provide AOD data for a strategically important region, i.e., Northeast Asia. The domain covered by the GOCI sensor shown in Fig. 1 is $2500 \mathrm{~km} \times 2500 \mathrm{~km}$ and includes eastern parts of China, the Korean peninsula, and Japan. The GOCI-retrieved AOD products were integrated with CMAQ-simulated AOD data to produce the more accurate aerosol data set used to investigate the impacts of transboundary PM pollution between the source and receptor countries in Northeast Asia.

\section{Methods}

The procedure to produce GOCI-constrained AOD product combines the GOCI level 2 product with AOD predictions from the US EPA Model-3/CMAQ (Community Multi-scale Air Quality) v4.5.1 model simulations. The CMAQ model simulations were performed over East Asia, with emission data prepared appropriately for the model domain and meteorological fields produced from the PSU/NCAR MM5 (the fifth generation meteorological model) simulations. The final AOD product is spatially continuous and available even for locations where GOCI retrievals are not available (e.g., cloud-contaminated points, sun-glint areas, desert, and snowcovered land). The use of GOCI-retrievals overcomes the "temporal limitation" typical in analyses with LEO (low Earth orbit) aerosol data and the assimilation overcomes the "spatial limitation" that has been typical in analyses based only on satellite data. The assimilated AOD data set using the GOCI data is utilized to monitor and evaluate transboundary particulate pollution from China to the Korean peninsula in this study. 
Table 1. Brief descriptions of aerosol optical property retrievals from some geostationary satellites.

\begin{tabular}{|c|c|c|c|c|c|c|c|}
\hline $\begin{array}{l}\text { Satellite \& } \\
\text { Sensor }\end{array}$ & $\begin{array}{l}\text { GMS5 }^{1} \\
\text { VISSR }^{7}\end{array}$ & $\begin{array}{l}\text { MTSAT-1 R } \\
\text { JAMI }^{8}\end{array}$ & $\begin{array}{l}\text { MSG }^{3} \\
\text { SEVIRI }^{9}\end{array}$ & $\begin{array}{l}\text { GOES } \\
\text { GOES-8 }\end{array}$ & $\begin{array}{l}\text { COMS }^{5} \\
\text { GOCI }^{10}\end{array}$ & $\begin{array}{l}\text { GOES-R } \\
\text { ABI }^{11}\end{array}$ & $\begin{array}{l}\text { GEO-KOMPSAT }^{6} \\
\text { GEMS }^{12} \& \text { ABI \& } \\
\text { GOCI-2 }\end{array}$ \\
\hline Sensor type & MET $^{13}$ sensor & MET sensor & MET sensor & MET sensor & Ocean color imager & MET sensor & $\begin{array}{l}\text { Environ. \& ocean } \\
\text { color imager }\end{array}$ \\
\hline Temporal resolution & $1 \mathrm{~h}$ & $30 \mathrm{~min}$ & $15 \mathrm{~min}$ & $15 \mathrm{~min}$ & $1 \mathrm{~h}$ & $\mathrm{TBD}^{17}$ & $1 \mathrm{~h}($ GEMS $)$ \\
\hline Spatial resolution & ${ }^{\mathrm{a}} 1.25 \mathrm{~km} /{ }^{\mathrm{b}} 5 \mathrm{~km}$ & $1.25 \mathrm{~km} / 5 \mathrm{~km}$ & $1 \mathrm{~km} / 3 \mathrm{~km}$ & $1 \mathrm{~km} / 4 \mathrm{~km}$ & $0.5 \mathrm{~km} / 0.5 \mathrm{~km}$ & $0.5 \mathrm{~km} / 2 \mathrm{~km}$ & $0.25 \mathrm{~km} / 1 \mathrm{~km}$ \\
\hline Number of bands & $1 \mathrm{VIS}^{14} / 3 \mathrm{IR}^{16}$ & $1 \mathrm{VIS} / 4 \mathrm{IR}$ & $\begin{array}{l}2 \mathrm{VIS} / 2 \mathrm{NIR}^{15} / \\
8 \mathrm{IR}\end{array}$ & $1 \mathrm{VIS} / 4 \mathrm{IR}$ & $6 \mathrm{VIS} / 2$ NIR & $\begin{array}{l}2 \mathrm{VIS} / 4 \mathrm{NIR} / \\
10 \mathrm{IR}\end{array}$ & $13 \mathrm{VIS} / \mathrm{NIR}$ \\
\hline Covering region & $\begin{array}{l}\text { East Asia } \\
\text { \& western Pacific Ocean }\end{array}$ & $\begin{array}{l}\text { East Asia } \\
\text { \& western Pacific Ocean }\end{array}$ & $\begin{array}{l}\text { Central } \\
\text { Europe }\end{array}$ & $\begin{array}{l}\text { Eastern } \\
\text { US }\end{array}$ & $\begin{array}{l}\text { Northeast } \\
\text { Asia }\end{array}$ & US & $\begin{array}{l}\text { East, Southeast } \\
\& \text { Central Asia }\end{array}$ \\
\hline Launch year & Mar 1995 & Feb 2005 & Aug 2002 & Apr 1994 & Jun 2010 & $\begin{array}{l}\text { Scheduled to be } \\
\text { launched in } 2015\end{array}$ & $\begin{array}{l}\text { Scheduled to be } \\
\text { launched in } 2018\end{array}$ \\
\hline References & $\begin{array}{l}\text { Masuda et al. (2002); } \\
\text { Wang et al. (2003) }\end{array}$ & Kim et al. (2008) & Popp et al. (2007) & $\begin{array}{l}\text { Christopher et al. (2002); } \\
\text { Knapp et al. }(2002,2005)\end{array}$ & $\begin{array}{l}\text { Lee et al. (2010); } \\
\text { this study }\end{array}$ & Laszlo et al. (2008) & \\
\hline
\end{tabular}

\subsection{Meteorology and chemistry-transport model simulations}

The PSU/NCAR MM5 and US EPA Model-3/CMAQ model v4.5.1 were respectively used as the meteorological model (MM) and chemistry-transport model (CTM) in this study (Byun and Schere, 2006; Park et al., 2011). The accuracy of the MM5 simulations was enhanced by nudging with the observed meteorological data (Grell et al., 1995). Initial conditions (ICs) and boundary conditions (BCs) for the MM5 simulations were updated continuously with the National Centers for Environmental Prediction (NCEP) reanalysis data. The latest remotely sensed surface wind data retrieved from the Advanced SCATterometer (ASCAT), which was launched on 19 October 2006 onboard the Meteorological Operational satellite A (MetOp-A) was used for the four-dimensional data assimilation (FDDA), since during regional-scale, long-range transport events the significant fractions of air pollutants are frequently transported through the marine boundary layer (MBL) between countries in Northeast Asia (e.g., through the MBL over the Yellow Sea between China and Korea and through the MBL over the East China Sea between China and Japan; regarding the locations of the Yellow Sea and the East China Sea, refer to Fig. 1) (Daum et al., 1996; Rajeev et al., 2000; Song et al., 2007).

The schemes chosen for CMAQ model simulations were the same as those used in previous research (Park et al., 2011). The SAPRC-99 chemical mechanism and AERO4 aerosol module were selected for simulating gas-phase chemistry and atmospheric aerosol thermodynamic/dynamic processes, respectively. More details of the MM5 and CMAQ model simulations were described in a previous publication (Park et al., 2011).

The CMAQ model simulations were carried out using the best available emission inventories over East Asia that have been made more sophisticated with, for example, the applications of monthly variations of anthropogenic emissions, the uses of an operational dust forecast model at the KMA (Korea Meteorological Administration) and the NCAR (Na-

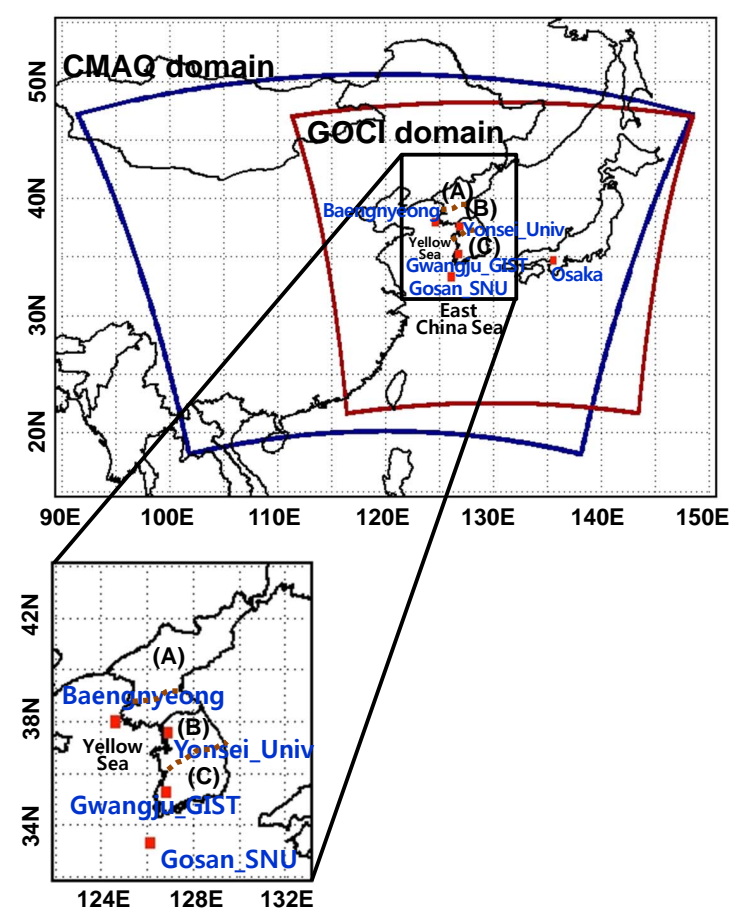

Fig. 1. Domains of CMAQ model simulations (in blue) and COMS/GOCI sensor (in red). Also shown are five AERONET sites in the receptor areas (Korea and Japan). For the sake of analytical convenience, three subregions (A), (B), and (C) in the Korean peninsula are defined; these represent the northern, central, and southern parts of the Korean peninsula, respectively.

tional Center for Atmospheric Research) FINN (Fire Inventory from NCAR) biomass-burning (BB) emissions (Wiedinmyer et al., 2011). The efforts are summarized in Table 2. For the consideration of anthropogenic pollutants emissions, such as $\mathrm{NO}_{\mathrm{x}}, \mathrm{SO}_{2}, \mathrm{CO}$, black carbon (BC), NMVOCs, etc., Intercontinental Chemical Transport Experiment-Phase B (INTEX-B), Regional Emission inventory in Asia (REAS), and Clean Air Policy Support System (CAPSS) were applied 
as the best suitable emission data over China, Japan, and the Korean peninsula, respectively. These emission inventories originally adjusted to the year 2006 were updated for the year 2011 modeling period, using the projection factors based on the Greenhouse gas and Air pollution INteractions and Synergies (GAINS) modeling emissions scenarios (http://gains.iiasa.ac.at/index.php/gains-asia). In the meanwhile, in order to consider isoprene and monoterpene emissions over the modeling domain, the isoprene emissions from Model of Emissions of Gases and Aerosols from Nature (MEGAN) and MOdel for Hydrocarbon emissions by the CANopy (MOHYCAN) were utilized for the CMAQ modeling input data (Müller et al., 2008). Monoterpene emissions were also estimated from the isoprene emissions, using the ratios of monoterpene to isoprene from Global Emissions Inventory Activity (GEIA).

In particular, this modeling period (a spring season in Northeast Asia) could not be explained without considering the effects of BB and mineral dust emissions. FINNv1 is a BB emission inventory annually provided from the year 2002 by NCAR (http://bai.acd.ucar.edu/Data/fire/). This FINNv1 has produced the $\mathrm{BB}$ emission data with a high horizontal resolution of $\sim 1 \mathrm{~km} \times 1 \mathrm{~km}$ over the entire globe, being applied for variable regions from local to global scales (Wiedinmyer et al., 2011). In this study, the FINNv1 was used for the BB emissions. The CMAQ v4.5.1 model does not include any dust modeling modules related to occurrence and transport of mineral dust events. However, without taking the influence of mineral dust events into account, accurate estimation of the aerosols effects observed by long-range transports in the Korean peninsula and Japan would not be possible. Therefore, the outbreak and transport of Asian mineral dust were considered by Asian Dust Aerosol Model (ADAM) simulations. The ADAM is currently operational model for forecasting Asian mineral dust events at the KMA and the details of the ADAM simulations were reported previously by e.g., Park and Lee (2004), Kim et al. (2011), and Park et al. (2011).

The domain of the CMAQ model simulation is also shown in Fig. 1. The CMAQ domain (blue color) covered the region of approximately $95-145^{\circ} \mathrm{E}, 20-50^{\circ} \mathrm{N}$, which includes COMS/GOCI domain (red color) composed of Northeast China, the Korean peninsula, and Japan. In this study, the CMAQ domain was chosen to be larger than the GOCI domain, since the air quality inside the GOCI domain is strongly influenced by the influxes from the outer areas with persistent westerlies in East Asia. The horizontal grid spacing of the CMAQ modeling was $30 \mathrm{~km} \times 30 \mathrm{~km}$ and the vertical domain was distributed in 14 layers following $\sigma$ coordinate from $1000 \mathrm{hPa}$ to $70 \mathrm{hPa}$. The MM5-CMAQ simulation period started at 00:00 UTC, 1 April to 23:00 UTC, 31 May 2011 (with a week-long CMAQ spin-up period), since the first batch of the level1 radiance data from the COMS/GOCI data center was released for this period.

\subsection{Remote-sensing data}

\subsubsection{COMS/GOCI data}

Sensors onboard LEO satellites, such as MODIS (Moderate Resolution Imaging Spectroradiometer) and MISR (Multiangle Imaging Spectroradiometer), have ordinarily been utilized to obtain information on aerosol optical properties (AOPs), but their monitoring has taken place at most once per day. To more accurately monitor the transboundary LRT events of air pollutants, hourly (or highly temporally resolved) monitoring data from geostationary Earth orbit (GEO) sensors are needed instead of the temporally limited LEO measured data. As mentioned previously and also presented in Table 1, MSG, GOES, and MTSAT-1R sensors have been partly monitoring the AOPs over Europe, US, and Japan, respectively (Knapp et al., 2005; Popp et al., 2007; Kim et al., 2008), but these meteorological sensors are equipped with only one visible channel, which possibly makes the quality of the AOPs from these meteorological sensors less accurate. In contrast, GOCI sensor onboard geostationary COMS has six visible bands at 412 , $443,490,555,660,680 \mathrm{~nm}$, which can make advances by more accurately calculating the AOPs, compared to other meteorological GEO satellite sensors. In addition, atmospheric compensations, such as cloud-screening make the numerical accuracy of the AOPs more improved, because the COMS/GOCI has 2 more bands at $745 \mathrm{~nm}$ and $865 \mathrm{~nm}$ (i.e., near IR). The GOCI sensor covers Northeast China, the Korean peninsula, and Japan, and the products can be generated with $500 \mathrm{~m} \times 500 \mathrm{~m}$ spatial resolution. GOCI level 1 data during daytime can be obtained eight times from 09:00 to 16:00 LST (local standard time) (refer to http://kosc.kordi. re.kr/oceansatellite/coms-goci/introduction.kosc).

The hourly GOCI level 1 data is released somewhat slowly after the IOT and data calibration procedures. The GOCI level 1 radiance is then converted into level 2 AOD data using a multi-spectral algorithm being developed by Jhoon Kim and coworkers at Yonsei University, Korea (Lee et al., 2010). The level 2 AOD data retrieved with a pixel size of $6 \mathrm{~km} \times 6 \mathrm{~km}$ was used in this study. The retrieval algorithm was originally based on the NASA MODIS (i.e., LEO) algorithm, but it has evolved to date to include the aerosol models optimized for East Asia and to consider the geometry from GEO satellite instruments such as GOCI, GOCI-2, and GEMS (Geostationary Environment Monitoring Spectrometer) (both the GOCI-2 and GEMS sensors are scheduled to be launched in 2018). The Yonsei aerosol retrieval algorithm includes the capability to classify aerosol types based on absorption tests and size information (Kim et al., 2007; Lee et al., 2010). The evaluation of the current AOD data from the algorithm shows that the slope of the linear regression line is close to 1.03 over ocean, but 1.15 over land when compared to values from AERONET. Although the detailed explanation and validation procedures of this Yonsei aerosol 
Table 2. Emission inventories used in the CMAQ model simulations.

\begin{tabular}{|c|c|c|}
\hline Region & Emission inventory & Species \\
\hline \multirow[t]{2}{*}{ China and North Korea } & INTEX-B $^{1}$ & $\mathrm{SO}_{2}, \mathrm{NO}_{\mathrm{x}}, \mathrm{NMVOCs}, \mathrm{CO}, \mathrm{CO}_{2}, \mathrm{BC}, \mathrm{OC}$ \\
\hline & EDGAR $^{2}$ & $\mathrm{NH}_{3}$ \\
\hline \multirow[t]{2}{*}{ South Korea } & CAPSS $^{3}$ & $\mathrm{SO}_{2}, \mathrm{NO}_{\mathrm{x}}, \mathrm{NMVOCs}, \mathrm{CO}, \mathrm{NH}_{3}$ \\
\hline & INTEX-B & $\mathrm{CO}_{2}, \mathrm{BC}, \mathrm{OC}$, Chemical split factors of NMVOCs \\
\hline Japan & REAS $^{4}$ & $\mathrm{SO}_{2}, \mathrm{NO}_{\mathrm{x}}, \mathrm{NMVOCs}, \mathrm{CO}, \mathrm{CO}_{2}, \mathrm{NH}_{3}, \mathrm{BC}, \mathrm{OC}$ \\
\hline \multirow[t]{4}{*}{ Entire domain } & GAINS $^{5}$ emission scenarios & ${ }^{\mathrm{a}}$ Interannual variations of $\mathrm{CO}, \mathrm{NO}_{\mathrm{x}}, \mathrm{VOC}, \mathrm{SO}_{2}, \mathrm{NH}_{3}, \mathrm{CO}_{2}, \mathrm{CH}_{4}, \mathrm{PM}_{2.5}$ \\
\hline & FINN $^{6}$ fire emissions & $\mathrm{CO}, \mathrm{NO}, \mathrm{NO}_{2}, \mathrm{SO}_{2}, \mathrm{NH}_{3}, \mathrm{NMVOCs}, \mathrm{BC}, \mathrm{OC}, \mathrm{PM}_{2.5}, \mathrm{PM}_{10}$ \\
\hline & MEGAN $^{7}+\mathrm{MOHYCAN}^{8}$ & Isoprene \\
\hline & GEIA $^{9}$ & ${ }^{b}$ Ratios of monoterpene to isoprene \\
\hline
\end{tabular}

${ }^{1}$ INTEX-B: Intercontinental Chemical Transport Experiment-Phase B, ${ }^{2}$ EDGAR: Emission Database for Global Atmospheric Research, ${ }^{3}$ CAPSS: Clean Air Policy Support System, ${ }^{4}$ REAS: Regional Emission inventory in ASia, ${ }^{5}$ GAINS: Greenhouse gas and Air pollution INteractions and Synergies, ${ }^{6}$ FINN: Fire Inventory from NCAR,

${ }^{7}$ MEGAN: Model of Emissions of Gases and Aerosols from Nature, ${ }^{8}$ MOHYCAN: MOdel for Hydrocarbon emissions by the CANopy, ${ }^{9}$ GEIA: Global Emissions Inventory Activity, ${ }^{\mathrm{a}}$ Emission increase (or decrease) rates from 2006 to 2011 for the air pollutants were obtained from the GAINS emission scenarios, ${ }^{\mathrm{b}}$ Monoterpene emissions are not included in MEGAN+MOHYCAN emissions. Therefore, the ratios of monoterpene to isoprene in the biogenic emissions were obtained from the GEIA emission inventory.

retrieval algorithm were given in previous publications (Lee et al., 2010, 2012), a brief introduction on the algorithm is made here. The retrievals of the AOPs were performed with top of atmosphere spectral reflectances. To obtain the AOPs over the regions including clouds, clouds are screened by spatial variability and threshold tests at each pixel. Even so, there are limitations to the complete removal of clouds and the perfect retrieval of surface reflectance due to the lack of IR bands on GOCI. Therefore, the Yonsei aerosol retrieval algorithm eliminates clouds utilizing a meteorological imager (MI) that has 4 IR channels. The MI sensor is also onboard COMS with GOCI. In addition, the Yonsei aerosol retrieval algorithm is composed of two different retrieval logics that are applied to "continent" including near-coastal turbid water areas and "ocean", respectively.

Figure 2 presents one example: a comparison of the Terra/MODIS-retrieved and Aqua/MODIS-retrieved AODs with GOCI-retrieved AODs at approximately 10:00 LST and 13:00 LST on 10 April and 12 April, respectively. As shown in Fig. 2, there are agreements in the spatial AOD distributions from the two MODIS and GOCI sensors. As discussed previously, at most two snapshots of information per day from the LEO sensors (i.e., MODIS) can be obtained, whereas eight snapshots per day from the GEO sensor (i.e., GOCI) are available. This is an obvious "temporal" advantage that can be achieved from the GEO sensor. Furthermore, as shown in Fig. 2, the AOD data from the GOCI sensor shows a better spatial coverage, compared to those from the MODIS (see white bands along the north-south swath in the MODIS data). This lack of the MODIS data was caused by sun-glint over the ocean areas (details about the sun-glint effects are discussed further in Appendix A). By contrast, such lack of the data is not found in the GOCI data. This is another "spatial" advantage that can be achieved with the GEO sensor. (a) MODIS-retrieved AOD (b) GOCl-retrieved AOD
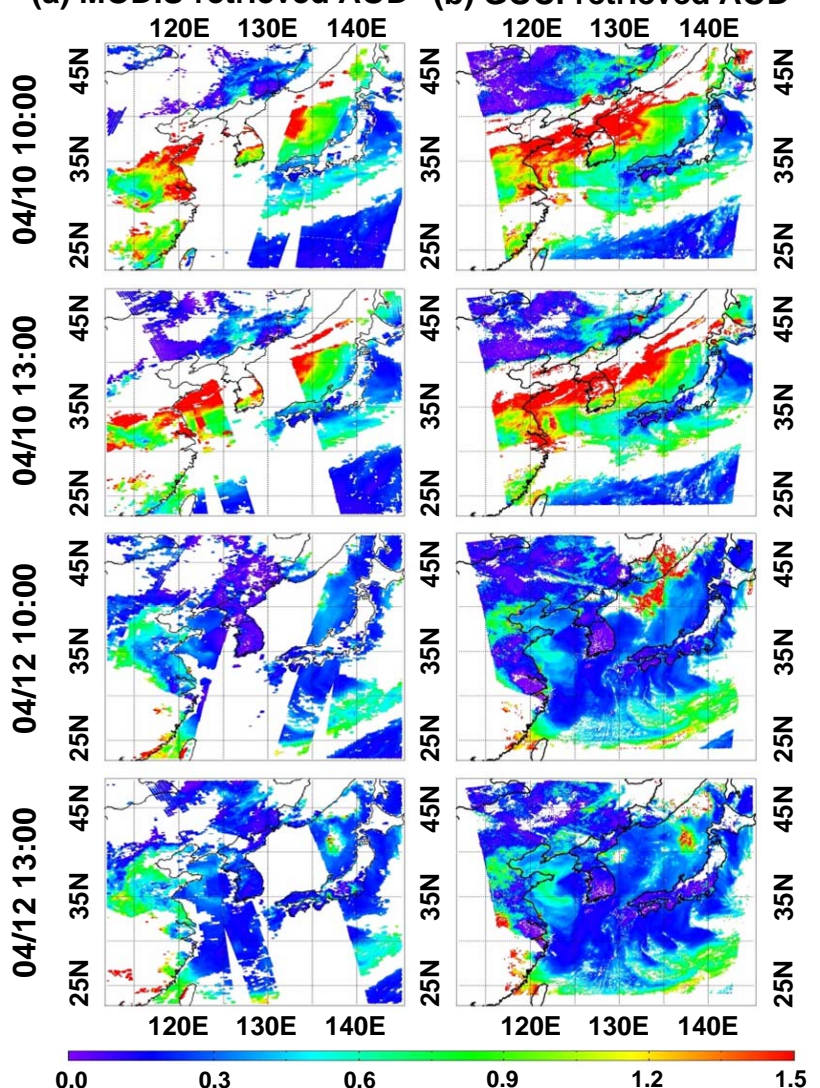

Fig. 2. Snapshots of (a) Terra and Aqua/MODIS-retrieved AODs and (b) GOCI-retrieved AOD over Northeast Asia at 10:00 LST (Terra/MODIS) and 13:00 LST (Aqua/MODIS) on 10 April and 12 April. 


\subsubsection{AERONET}

Many studies have used the ground-based NASA AERONET data to verify modeling results and satellite monitoring data (e.g., Chin et al., 2002, 2004; Yumimoto and Takemura, 2011). The AERONET data measured by sun photometers were utilized in this study to investigate the accuracy of CMAQ model simulations and GOCI AOP data.

In this manuscript, the data obtained from five AERONET observation sites (i.e., Baengnyeong, Yonsei University (Yonsei_Univ), GIST (Gwangju_GIST), Gosan (Gosan_SNU), and Osaka) in the Korean peninsula and Japan were selected in order to analyze long-range transport effects over Northeast Asia. The AERONET AOD level 2.0 data used for comparison was obtained from the official NASA web site at http://aeronet.gsfc.nasa.gov. The only exception was the AERONET AOD data for the Yonsei University (Seoul) site, which were not calibrated. Before use, they were upgraded by eliminating some sporadic cloud contamination of the initial high AOD data (AOD>1.0) using the meteorological data from the automatic weather stations (AWS) colocated with Cimel sun photometers. The uncertainty and possible anomalies in the Cimel sun photometer AOD data at the Yonsei University site were also checked by the Laboratory for Terrestrial Physics at NASA Goddard Space Flight Center. AOD uncertainties of 0.01 to 0.04 were estimated, mainly due to calibration.

\subsection{AOD calculations from CMAQ model simulations}

Concentrations of nitrate, sulfate, ammonium, organic aerosols (OAs), BC, sea-salt aerosols, and mineral dust are provided as results of the CMAQ model simulations. This aerosol composition can be converted into the AOPs including AOD by considering the mass extinction efficiencies (MEEs) depending on the scattering and absorbing characteristics for each aerosol composition and the hygroscopicity. First, the absorption, scattering, and extinction coefficients ( $\sigma_{\text {abs }}, \sigma_{\text {scat }}$, and $\sigma_{\text {ext }}$ ) were calculated by the following formulas:

$\sigma_{\text {ext }}(\lambda)=\sigma_{\text {abs }}(\lambda)+\sigma_{\text {scat }}(\lambda)$,

$\sigma_{\mathrm{abs}}\left(\lambda: \mathrm{Mm}^{-1}\right)=\sum_{i}^{n} \sum_{j}^{m}\left\{\left(1-\omega_{i j}(\lambda)\right) \cdot \beta_{i j}(\lambda) \cdot f_{i j}(\mathrm{RH}) \cdot[C]_{i j}\right\}$,

$\sigma_{\text {scat }}\left(\lambda: \mathrm{Mm}^{-1}\right)=\sum_{i}^{n} \sum_{j}^{m}\left\{\omega_{i j}(\lambda) \cdot \beta_{i j}(\lambda) \cdot f_{i j}(\mathrm{RH}) \cdot[C]_{i j}\right\}$,

where $i$ and $j$ represent the particulate species $i$ at the size bin or particle mode $j ; f_{i j}(\mathrm{RH})$ the hygroscopic enhancement factor as a function of relative humidity $(\mathrm{RH}) ;[C]_{i j}$ the concentrations of particulate species such as $\left(\mathrm{NH}_{4}\right)_{2} \mathrm{SO}_{4}$, $\mathrm{NH}_{4} \mathrm{NO}_{3}, \mathrm{BC}, \mathrm{OAs}$, mineral dust, and sea-salt aerosols; and $\omega_{i j}(\lambda)$ and $\beta_{i j}(\lambda)$ the single scattering albedo and MEE of particulate species $i$ at the size bin or particle mode $j$, respectively. The terms related to the MEEs $\left(\beta_{i j}\right)$ and the hygroscopicity $\left(f_{i j}(\mathrm{RH})\right)$ have been defined differently in several studies, e.g., d'Almeida et al. (1991), Malm et al. (1994), Chin et al. (2002), Malm and Hand (2007), and Park et al. (2011). According to the previous investigations, the way to compute the extinction coefficients $\left(\sigma_{\text {ext }}\right)$ has been mainly classified into two categories. The first method is to use empirical equations (e.g., Malm et al., 1994; Malm and Hand, 2007; Song et al., 2008; Park et al., 2011). The other method is to use the equations obtained based on the Mie theory (e.g., d'Almeida et al., 1991; Chin et al., 2002). In this study, the methods from Chin et al. (2002) and Park et al. (2011) were mainly utilized and compared.

Based on the particulate composition and meteorological parameters obtained from the MM5-CMAQ model simulations, the AOD was calculated at a wavelength of $550 \mathrm{~nm}\left(\mathrm{AOD}_{550}\right)$, using the conversion algorithms of Chin et al. (2002), Park et al. (2011), and others (d'Almeida et al., 1991; Malm et al., 1994; Hess et al., 1998; Malm and Hand, 2007):

$\operatorname{AOD}_{550}=\int_{0}^{z} \sigma_{\text {ext }}(550 \mathrm{~nm}) \mathrm{d} z$,

where $z$ represents the vertical height. For example, the CMAQ-simulated AOD products calculated from Park et al. (2011) usually showed underestimations when compared to the AERONET AOD data. However, when Chin et al.'s (2002) conversion algorithm was applied, the AOD values were usually larger than those calculated by Park et al.'s (2011) method. These results will be discussed further in a later section.

\subsection{Data assimilation}

In several previous studies, optimal interpolation (OI) technique with a Kalman gain matrix has been employed to improve the predictions of AOD and aerosol mass distributions with the combination of the modeling results and monitoring data (Collins et al., 2001; Yu et al., 2003; Adhikary et al., 2008; Chung et al., 2010; Park et al., 2011). For example, Adhikary et al. (2008) showed some enhancements in the estimations of the AOD values over Asia by combining the STEM-modeled and MODIS-retrieved data through the OI technique. The accuracy of the AOD values was also greatly improved after the application of the OI method using CMAQ-simulated and MODIS-retrieved AOD data $\left(\mathrm{AOD}_{\mathrm{m}}\right.$ and $\mathrm{AOD}_{\mathrm{o}}$ in Eq. 5) (Park et al., 2011).

$\mathrm{AOD}_{\mathrm{m}}^{\prime}=\mathrm{AOD}_{\mathrm{m}}+\mathbf{K}\left[\mathrm{AOD}_{\mathrm{o}}-\mathbf{H}\left(\mathrm{AOD}_{\mathrm{m}}\right)\right]$,

$\mathbf{K}=\mathbf{B} \mathbf{H}^{T}\left(\mathbf{H B H}^{T}+\mathbf{O}\right)^{-1}$,

where $\mathbf{H}$ denotes a linear operator for interpolation from the modeling grid to the satellite retrieval grid. $\mathbf{B}$ and $\mathbf{O}$ represent 
the error covariances of the modeling and satellite (observation) fields, respectively.

In this study, the OI technique was again utilized for the assimilation of the AOD data from the GOCI sensor into the CMAQ model. The Kalman gain matrix (K in Eq. 6) was obtained by the covariance of modeled and observed fields ( $\mathbf{B}$ and $\mathbf{O}$ in Eq. 6) which is a function of free parameters. The yearly fixed free parameters were mainly used in several previous studies (Collins et al., 2001; Yu et al., 2003; Adhikary et al., 2008; Chung et al., 2010), whereas Park et al. (2011) proposed applying seasonal variations of free parameters. The best free parameters for four seasons suggested in Park et al. (2011) were used here. Detailed explanations of the OI technique including the selection of the free parameters were made in Park et al. (2011). The assimilated AOD data produced by combining the CMAQ-simulated and the GOCI-retrieved AODs were used to investigate the longrange PM transport events in this study.

\subsection{Long-range transport of particulate matter}

Transboundary transports of the AOD plumes from the China continent to the Korean peninsula and Japan were the focus of this study. However, defining the LRT events over Northeast Asia is not easy, mainly due to complexities in air mass movements. We considered large-scale AOD plumes that caused the peak AOD values larger than 0.4 at the receptor sites ("peak AOD filter"). Such LRT AOD plumes were further traced back via NOAA HYSPLIT (HYbrid SingleParticle Lagrangian Integrated Trajectory) model analysis (Draxler and Hess, 1998) from the points of time when the peak AOD values occurred. The HYSPLIT model simulations were performed with meteorological data, which were taken from the GDAS (Global Data Assimilation System) of NCEP. When the backward trajectories from the occurring points of the peak AOD values had passed through China within $48-72 \mathrm{~h}$, the AOD plumes were finally determined to be LRT plumes ("backward trajectory filter"). A LRT case shown in Fig. 3 was decided by using both of the filters. For example, $72 \mathrm{~h}$ HYSPLIT backward trajectory analysis at three AERONET receptor sites in Korea for the LRT case in Fig. 3 is presented in Fig. 4. As shown, all the backward trajectories were passed through China. By contrast, Fig. 5 shows an example of a non-LRT case. Both the LRT and nonLRT cases will be discussed further in Sect. 3.1.

In order to investigate the LRT of particulate matter over Northeast Asia, the AOD values instead of PM concentrations were used. In other words, the AOD has been regarded as a proxy quantity for PM concentration in this study. In this context, relationships between $\mathrm{PM}_{10}$ (or $\mathrm{PM}_{2.5}$ ) and $\mathrm{AOD}$ can be important. The relationships are affected by various parameters, such as height of the PBL (planetary boundary layer), RH, vertical distribution of aerosols, seasonality, diurnal variation, geographical information, particle compositions, and size distributions (Wang and Christopher, 2003;

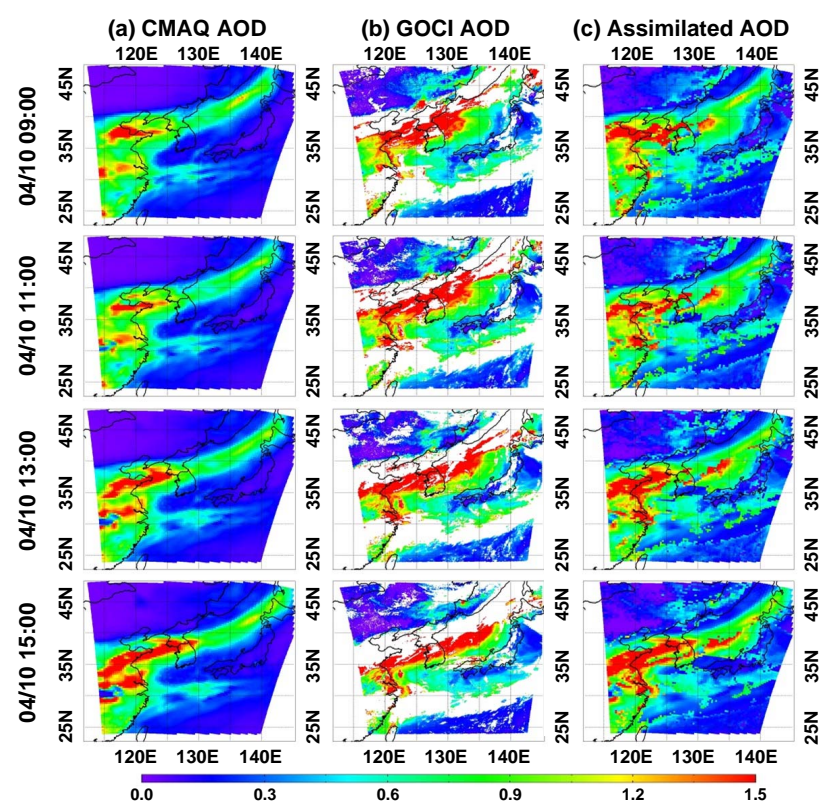

Fig. 3. Spatial and temporal distributions of (a) CMAQ-simulated AOD (calculated via Chin et al.'s (2002) conversion algorithm), (b) GOCI-retrieved AOD (retrieved via the Yonsei aerosol retrieval algorithm (Lee et al., 2010)) and (c) assimilated AOD with twohour resolution over Northeast Asia at 09:00, 11:00, 13:00, and 15:00 LST on 10 April 2011.

Engel-Cox et al., 2004; Liu et al., 2005; van Donkelaar et al., 2006; Choi et al., 2009; Schaap et al., 2009; Tsai et al., 2011). Several studies have estimated two-dimensional $\mathrm{PM}_{10}$ from the relationships between ground-based $\mathrm{PM}_{10}$ and satelliteretrieved AOD (Wang and Christopher, 2003; Engel-Cox et al., 2004; Liu et al., 2005; Schaap et al., 2009; Tsai et al., 2011) or the ratios of CTM-simulated $\mathrm{PM}_{10}$ to AOD (Liu et al., 2004; van Donkelaar et al., 2006; Choi et al., 2009).

\section{Results and discussions}

The hourly assimilated AOD data was used to identify and analyze the PM LRT events over Northeast Asia. Based on this, the variations of the AOD values during LRT events in comparison with those during non-LRT events were analyzed on a more quantitative basis.

\subsection{Long-range transport of aerosols from China to Korea}

A representative snapshot of an LRT event of particulate matter from China to the Korean peninsula, Japan, and the northwestern Pacific Ocean is presented in Fig. 3. It can be seen that a huge AOD plume (AOD>0.6) was generated in the greater Beijing area and Shandong province on 10 April and was then transported over long distances to the Korean peninsula following a low pressure trough. GOCI 


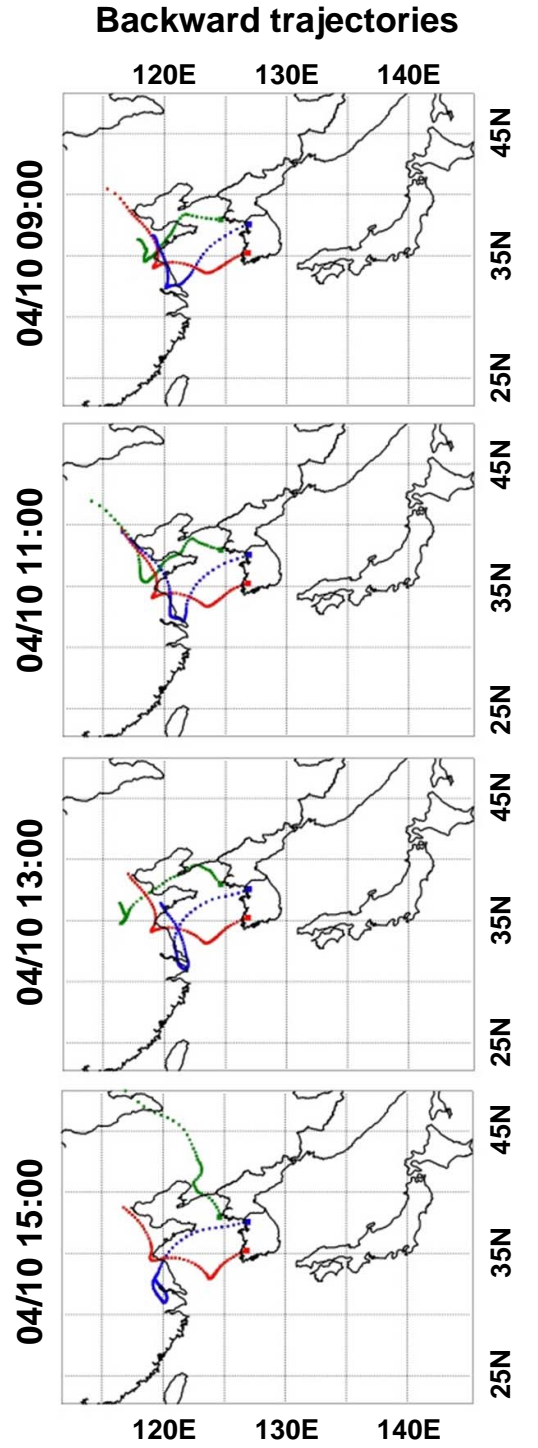

Fig. 4. NOAA HYSPLIT $72 \mathrm{~h}$ backward trajectory analysis at three Korean AERONET sites (Baengnyeong, Yonsei_Univ (Seoul), and Gwangju_GIST) with $2 \mathrm{~h}$ resolution at 09:00, 11:00, 13:00, and 15:00 LST on 10 April 2011.

retrievals with one-hour intervals from 09:00 to 16:00 LST (eight snapshots per day) on 10 April show high aerosol loadings (AOD > 1.2) over the Shandong peninsula and Shanghai regions that extend over Korea. The plumes extend farther out over the Yellow Sea and slowly shift to lower latitudes as time progresses. In Fig. 3, only two-hour resolution results are presented. It is important to note that GOCI AOD values are not retrieved in regions where clouds exist. As shown in Fig. 3, cloud-contaminated pixels appear white, which indicates that no data is available at these pixels. The GOCI retrievals, when assimilated into the CMAQ model, produce complete spatial distributions where AOD is estimated in all pixels (see the third column of Fig. 3). Therefore, the assim-

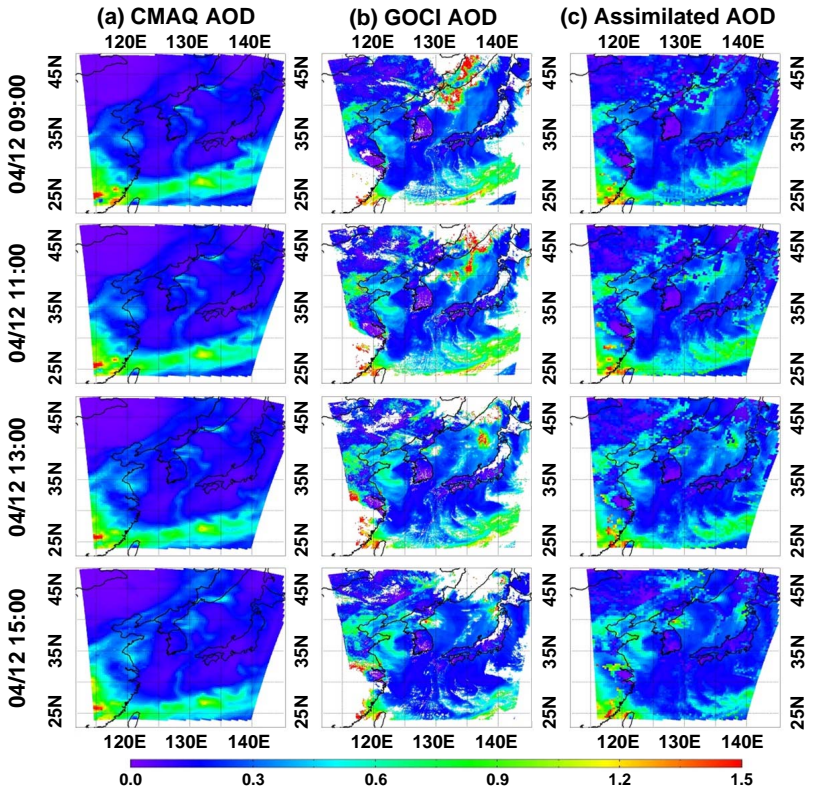

Fig. 5. As Fig. 3, for a non-LRT event on 12 April 2011. This case was determined as non-LRT because the main AOD plumes were transported into over northwestern Pacific Ocean, not over the Korean peninsula and/or Japan.

ilated AOD fields are much improved in comparison to the predicted (a priori) CMAQ AOD distributions (first column of Fig. 3). The a priori CMAQ AOD values have a tendency to be underestimated compared to the GOCI-retrieved AOD values, as shown in Fig. 3. This underestimation is believed to be related to uncertainties in the emission rates of gaseous and particulate pollutants and the CMAQ model simulations, as well as the uncertainties in the assumptions made during the AOD estimation from the CMAQ modeling results.

In this analysis, the AOD calculation via Chin et al.'s (2002) conversion method was used. However, several other estimations were also tested (e.g., Malm et al., 1994; Chin et al., 2004; Park et al., 2011). One example is shown in Fig. 6 and Table 3, which were produced by Park et al.'s (2011) conversion method. It was found that the AOD values were underestimated because the MEE values and hygroscopic enhancement factor $\left(f_{i j}(\mathrm{RH})\right)$ of Park et al.'s (2011) conversion method were reported to be in general smaller than those of Chin et al.'s (2002) method. After assimilation both the magnitudes and spatial distributions are significantly improved. The AOD LRT event shown in Fig. 3 is only an example. Seven to fourteen small- and large-scale AOD LRT events occurred over the two-month period (from 1 April to 31 May 2011).

Furthermore, the non-LRT events were also identified. During the non-LRT periods, air masses were generally stationary. Although the influx of air pollutants emitted from the highly polluted China regions to the Korean peninsula 
Table 3. Comparison analysis of the assimilated AOD for LRT and non-LRT events at five AERONET sites during the entire modeling period of 1 April to 31 May 2011.

\begin{tabular}{|c|c|c|c|c|c|c|c|c|c|c|c|}
\hline & \multicolumn{4}{|c|}{ Non-LRT events } & \multicolumn{4}{|c|}{ LRT events } & \multirow{2}{*}{$\begin{array}{l}\text { Data fraction of } \\
\text { LRT events } \\
\left(x_{\text {LRT }} \text { in Eq. } 8\right)\end{array}$} & \multirow{2}{*}{$\begin{array}{l}\text { AOD increase } \\
\text { during LRT } \\
\text { events }^{3}\end{array}$} & \multirow{2}{*}{$\begin{array}{c}\text { Ratio of AOD increase } \\
\text { during LRT } \\
\text { events }\end{array}$} \\
\hline & $N^{1}$ & $\sigma^{2}$ & Avg. & Max. & $N$ & $\sigma$ & Avg. & Max. & & & \\
\hline Baengnyeong & 849 & 0.11 & 0.16 & 0.95 & 606 & 0.36 & 0.59 & 2.15 & 0.42 & 0.43 & 2.59 \\
\hline Yonsei_Univ (Seoul) & 821 & 0.15 & 0.22 & 0.77 & 634 & 0.29 & 0.49 & 2.13 & 0.44 & 0.28 & 1.28 \\
\hline Gwangju_GIST & 1024 & 0.13 & 0.20 & 1.10 & 431 & 0.31 & 0.47 & 1.89 & 0.30 & 0.27 & 1.36 \\
\hline Gosan_SNU & 967 & 0.12 & 0.17 & 1.09 & 488 & 0.24 & 0.41 & 1.53 & 0.34 & 0.24 & 1.37 \\
\hline Osaka & 1247 & 0.11 & 0.16 & 1.16 & 208 & 0.21 & 0.39 & 1.23 & 0.14 & 0.23 & 1.41 \\
\hline Total & & 0.12 & 0.18 & 1.16 & & 0.31 & 0.49 & 2.15 & 0.33 & 0.31 & 1.68 \\
\hline
\end{tabular}

Table 4. Comparison analysis of the assimilated AOD for LRT and non-LRT events at five AERONET sites during the entire modeling period of 1 April to 31 May 2011.

\begin{tabular}{|c|c|c|c|c|c|c|c|c|c|c|c|}
\hline & \multicolumn{4}{|c|}{ Non-LRT events } & \multicolumn{4}{|c|}{ LRT events } & \multirow{2}{*}{$\begin{array}{l}\text { Data fraction of } \\
\text { LRT events } \\
\left(x_{\text {LRT }} \text { in Eq. } 8\right)\end{array}$} & \multirow{2}{*}{$\begin{array}{l}\text { AOD increase } \\
\text { during LRT } \\
\text { events }^{3}\end{array}$} & \multirow{2}{*}{$\begin{array}{c}\text { Ratio of AOD increase } \\
\text { during LRT } \\
\text { events }\end{array}$} \\
\hline & $N^{1}$ & $\sigma^{2}$ & Avg. & Max. & $N$ & $\sigma$ & Avg. & Max. & & & \\
\hline Baengnyeong & 849 & 0.12 & 0.22 & 0.98 & 606 & 0.48 & 0.79 & 2.79 & 0.42 & 0.57 & 2.65 \\
\hline Yonsei_Univ (Seoul) & 821 & 0.21 & 0.30 & 1.13 & 634 & 0.37 & 0.66 & 2.93 & 0.44 & 0.35 & 1.17 \\
\hline Gwangju_GIST & 1024 & 0.16 & 0.27 & 1.22 & 431 & 0.40 & 0.63 & 2.50 & 0.30 & 0.36 & 1.30 \\
\hline Gosan_SNU & 967 & 0.12 & 0.22 & 1.14 & 488 & 0.31 & 0.54 & 1.95 & 0.34 & 0.32 & 1.47 \\
\hline Osaka & 1247 & 0.11 & 0.21 & 0.90 & 208 & 0.22 & 0.48 & 1.26 & 0.14 & 0.27 & 1.27 \\
\hline Total & & 0.15 & 0.24 & 1.22 & & 0.40 & 0.65 & 2.93 & 0.33 & 0.40 & 1.67 \\
\hline
\end{tabular}

and Japan was significantly reduced, the stagnant weather conditions could seriously deteriorate air quality. Figure 5 shows a case of the non-LRT events. Noticeable aerosol plumes directly transported from China to the Korean peninsula and Japan could not be identified. Some AOD plumes were generated in the southern parts of China, and were then transported over the northwestern Pacific Ocean. This case was classified as non-LRT case since the AOD plumes were not directly transported to the Korean peninsula and/or Japan.

In addition, a high AOD plume (in the second column in Fig. 5) was transported through southern Russia (between 09:00 and 11:00 LST). This plume appears to be thin clouds (i.e., cloud optical depth (COD)). This can be confirmed partly via the Terra/MODIS AOD data at 10:30 LST on 12 April. The Terra/MODIS AOD data did not show any AOD plume over the same region (refer to the third and the fourth rows in Fig. 2). Since the GOCI AOD algorithm has limitations in completely eliminating clouds, thin clouds are sometimes considered aerosol plumes. Similar cases were also introduced by Al-Saadi et al. (2005) with the MODIS AOD data over the United States. Another possibility for this plume is that aerosols could be generated through Siberian forest fires. In order to check this possibility, the global MOZART (Model for OZone And Related chemical Tracers) model simulation data was investigated (http: //www.acd.ucar.edu/wrf-chem). But no Siberian fire significantly affected aerosol plumes on/before 12 April 2011.

The AOD LRT events were investigated at the five AERONET sites (Holben et al., 1998) in the Korean peninsula and in Japan shown in Fig. 1. The AERONET AOD values observed at ground sites are regarded as "ground truth" because the surface reflectance does not interfere with them (Holben et al., 1998; Dubovik et al., 2000; Chin et al., 2002, 2004; Park et al., 2011), and due to the high accuracy $(\sim 0.01-0.02)$ of the fully calibrated data (Eck et al., 1999). Figure 7 shows the comparison of the GOCIretrieved/assimilated AOD products (red horizontal bars and blue solid line in Fig. 7, respectively) with the AERONET 


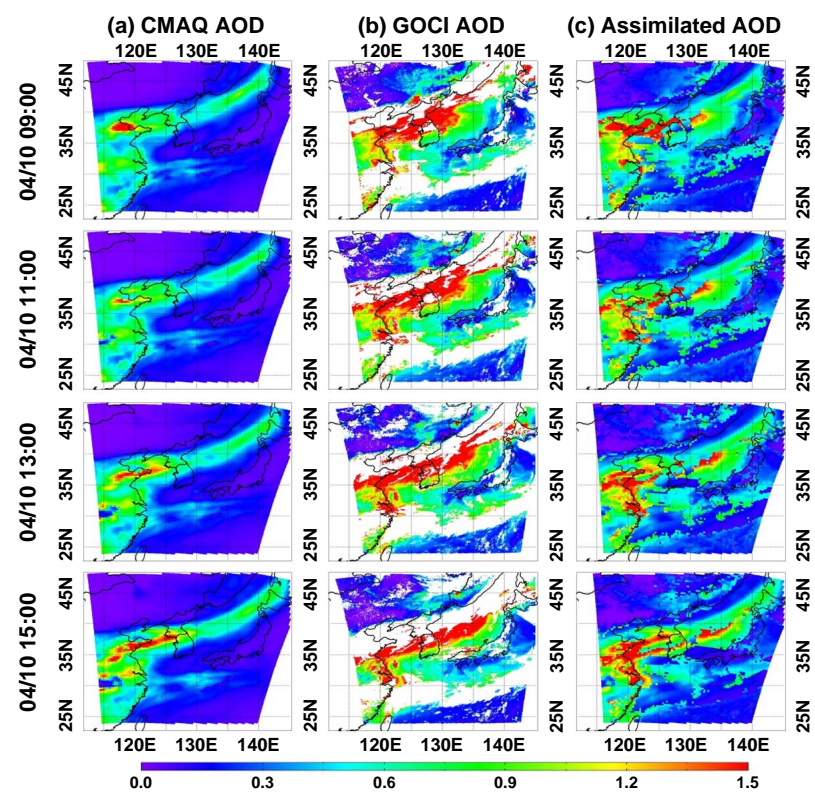

Fig. 6. As Fig. 3, except that the CMAQ-simulated AOD values were calculated via Park et al. (2011)'s conversion algorithm.

AOD data (black bars in Fig. 7). The GOCI-retrieved AOD values agree well with the AERONET values (e.g., $R=0.84$, see Table 5). However, both AERONET and GOCI data show large time periods with no retrievals, which points to the need for models to provide additional information. The assimilated AOD product is well correlated with the AERONET and GOCI-retrieved AOD values and is much more accurate than the a priori CMAQ AOD product when compared with the AERONET AOD values. This situation is summarized in Table 5, where the errors and biases after the assimilation become much smaller than those before the assimilation, indicating that the assimilation clearly improves the quality of the AOD products. The assimilated product provides a continuous estimate of the time series of AOD at every location, which the observations alone cannot (the red horizontal bars in Fig. 7 only cover limited time periods).

As discussed previously, the AOD values are related to surface PM concentrations. Figure 8 shows an example of how to estimate the surface PM concentrations from the assimilated AOD values. The daily averaged AOD values ((AOD) assimilated $)$ shown in Fig. 7 were converted into $\mathrm{PM}_{10}$ $\left(\left(\mathrm{PM}_{10}\right)_{\text {estimated }}\right)$ at five AERONET sites, using following proportional relationship (van Donkelaar et al., 2006):

$\left(\mathrm{PM}_{10}\right)_{\text {estimated }}=\left(\frac{\mathrm{PM}_{10}}{\mathrm{AOD}}\right)_{\text {simulated }} \times(\mathrm{AOD})_{\text {assimilated }}$.

Twenty-four hour $\mathrm{PM}_{10}$ was also measured simultaneously at three Korean AERONET locations by the Korean National Institute of Environmental Research (NIER). The observed $24 \mathrm{~h} \mathrm{PM}_{10}$ concentrations (black dots) were then plotted together with the daily averaged $\mathrm{PM}_{10}$ concentrations es- timated from Eq. (7) (grey bars) in Fig. 8. As shown, there are reasonable agreements between the two $\mathrm{PM}_{10}$ concentrations over two-month periods, except for several time windows such as 9-11 April and 13-17 May. This example (Fig. 8) is presented here in order to show how AOD is related to surface PM concentrations. Although reasonable agreements between the observed and estimated PM concentrations were shown in Fig. 8, the conversion methods should be further developed in order to more accurately convert AOD to $\mathrm{PM}_{10}$ (or $\mathrm{PM}_{2.5}$ ) over East Asia, with the consideration of more factors, such as height of PBL, RH, and presence of dust and BB plumes in the free troposphere (Wang and Christopher, 2003; Engel-Cox et al., 2004; Liu et al., 2005; van Donkelaar et al., 2006; Choi et al., 2009; Schaap et al., 2009; Tsai et al., 2011).

\subsection{Estimation of the impacts of long-range transport}

The grey-shaded areas in Fig. 7 represent the periods during which the receptors were affected by the PM LRT events. The PM LRT events were determined based on the meteorological fields generated from MM5 simulations together with comprehensive backward trajectory analysis. For example, the Baengnyeong site was affected by the small- and largescale LRT events fourteen times over the two-month period. Most of the high (and wide) AOD peaks are due to the largescale LRT events from China, and most of the small/sharp spikes are usually caused by local pollution under stagnant meteorological conditions. The grey-shaded periods in Fig. 7 usually start and end when the large-scale LRT AOD plumes arrive in and depart from the AERONET sites.

The background average AOD values (calculated excluding the AOD values during the LRT events) are represented by dashed lines at the five AERONET sites in Fig. 7. The average impact of the transboundary PM pollution over the entire two-month period (i.e., over "the non-LRT + LRT periods") was calculated using the following formula over the two-month period:

$\overline{\mathrm{AOD}}_{\mathrm{avg}}=\frac{\sum_{i=1}^{N}\left\{\overline{\mathrm{AOD}}_{\mathrm{LRT}} \times x_{\mathrm{LRT}}+\overline{\mathrm{AOD}}_{\mathrm{non}-\mathrm{LRT}} \times\left(1-x_{\mathrm{LRT}}\right)\right\}}{N}$,

$\overline{\mathrm{AOD}}_{\text {inc }}=\Delta \overline{\mathrm{AOD}}=\overline{\mathrm{AOD}}_{\mathrm{LRT}}-\overline{\mathrm{AOD}}_{\text {non-LRT }}$,

where $\overline{\mathrm{AOD}}_{\text {avg }}, \overline{\mathrm{AOD}}_{\text {non-LRT }}$, and $\overline{\mathrm{AOD}}_{\mathrm{LRT}}$ represent the average $A O D$ values during the entire period and the average AOD values calculated during the non-LRT and LRT periods, respectively. $x_{\mathrm{LRT}}$ is the fraction of the LRT events over the two-month period. $N$ is the total number of the grid cells being considered (for the calculation at an AERONET site, $N=1)$. After that, the average AOD increase $\left(\overline{\mathrm{AOD}}_{\text {inc }}\right)$ during the two-month period was calculated by Eq. (9). The results for the analysis for the AERONET sites are summarized in Table 4. From this analysis, the average AOD increase of $117-265 \%$ is found at the five AERONET sites. 


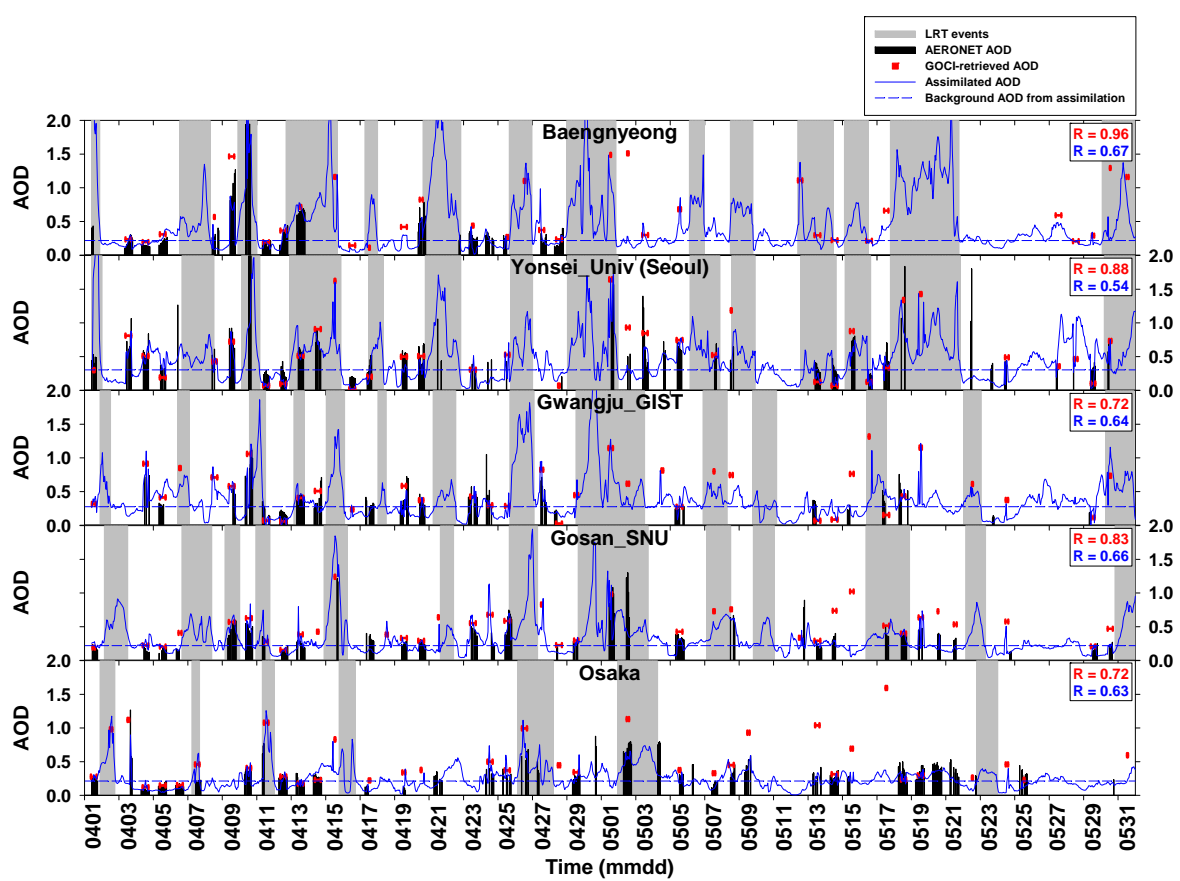

Fig. 7. Time series analysis of AERONET AOD (black bars) and two AOD products (red horizontal bars indicate the GOCI-retrieved AOD products; blue lines represent the assimilated AOD products) over the modeling period of 1 April to 31 May 2011 at five AERONET sites: Baengnyeong, Yonsei_Univ (Seoul), Gwangju_GIST, Gosan_SNU, and Osaka. The averaged background AODs estimated from the assimilated AOD values during non-LRT events are presented by blue dashed lines. Also, the periods of LRT events are displayed with grey-shaded areas.

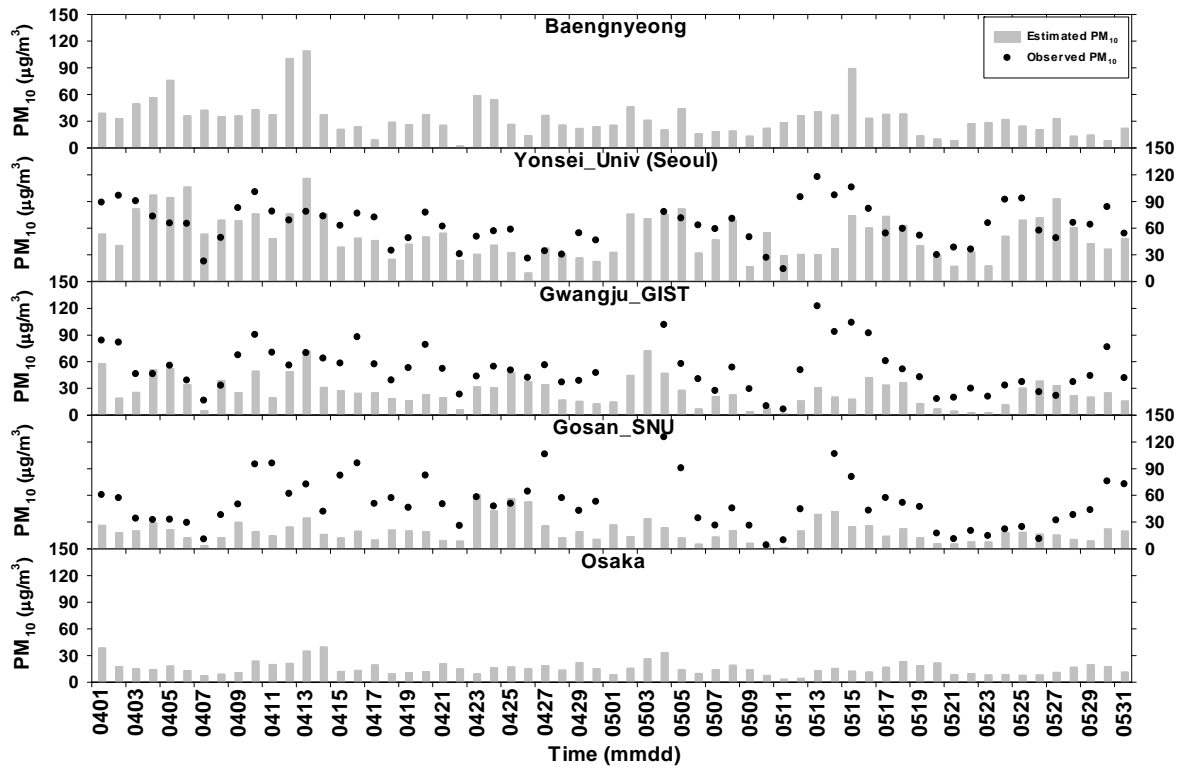

Fig. 8. Observed $\mathrm{PM}_{10}$ (black dots) vs. estimated $\mathrm{PM}_{10}$ (grey bars). Daily averaged estimated $\mathrm{PM}_{10}$ was converted from the assimilated AOD values at five AERONET sites. $24 \mathrm{~h}$ PM $_{10}$ was measured at three AERONET sites (Yonsei_Univ (Seoul), Gwangju_GIST, and Gosan_SNU). 
Table 5. Statistical analysis among AERONET, GOCI-retrieved, CMAQ-simulated, and assimilated AODs for the modeling period of 1 April to 31 May 2011.

\begin{tabular}{lcccccc}
\hline AOD & \multicolumn{5}{c}{ vs. AERONET } \\
\cline { 2 - 7 } $\begin{array}{l}\text { via Chin et al.'s } \\
\text { conversion algorithm } \\
\text { (Chin et al., 2002) }\end{array}$ & $N^{1}$ & $R^{2}$ & RMSE $^{3}$ & MNGE $^{4}$ & $\mathrm{MB}^{5}$ & $\mathrm{NMB}^{6}$ \\
\hline CMAQ & & & & & & \\
GOCI & 946 & 0.47 & 0.31 & 46.52 & -0.09 & -14.51 \\
Assimilation & 499 & 0.84 & 0.19 & 42.42 & -0.03 & -15.15 \\
\hline
\end{tabular}

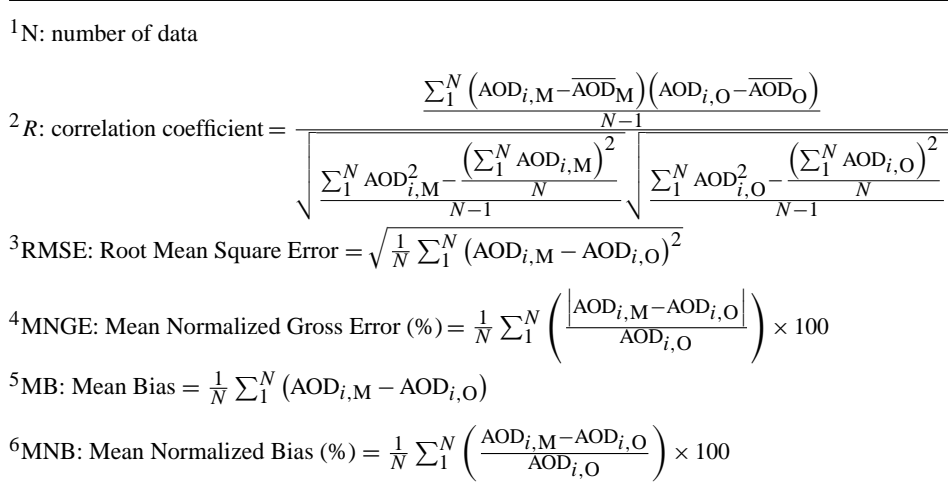

The average AOD increases due to the transboundary PM pollution over the Korean peninsula were estimated in a similar manner. The Korean peninsula (receptor) was divided into three subregions (northern Korea (A), central Korea (B), and southern Korea (C)) as shown in Fig. 1 to determine subregional differences in the degree of impact from the LRT events. The daily variations of the average AOD values over the three subregions (A), (B), (C), and the entire Korean peninsula are shown in Fig. 9. In panel (a) of Fig. 9, CMAQ-simulated AODs were estimated based on Chin et al.'s (2002) method, whereas in panel (b), AODs were calculated based on Park et al.'s (2011) algorithm . Panel (b) is presented here for the comparison purpose with panel (a). The daily and regionally averaged AOD values were presented by color codes in Fig. 9. As noticed from Fig. 9, some longrange PM transport events affected parts of the Korean peninsula (e.g., 10 and 21 April), while the entire Korean peninsula was also sometimes influenced by the long-range PM transport events (e.g., 1 May). The average AOD increases $\left(\overline{\mathrm{AOD}}_{\text {inc }}\right)$ calculated using Eqs. (8) and (9) in panel (a) of Fig. 9 were $128 \%, 121 \%$, and $112 \%$ over the subregions (A), (B), and (C), respectively, showing that northern Korea experienced the largest impact of the transboundary PM pollution from China during this period. The overall average estimated AOD increase over the entire Korean peninsula during the two-month period was $121 \%$. The daily and regionally averaged AOD values in panel (b) of Fig. 9 were in general smaller than those in panel (a), since Park et al.'s (2011) algorithm tends to produce smaller AOD values than Chin et al.'s (2002) algorithm, as discussed previously. Again, the differences resulting from different algorithms should be further investigated in the future.

\section{Summary and conclusions}

In this study, a new approach was introduced to more accurately monitor transboundary LRT events of particulate pollutants over Northeast Asia, combining the CMAQsimulated AOD with the GOCI-retrieved AOD via an OI technique (data assimilation). The PM LRT phenomena from China (source) to the Korean peninsula and Japan (receptor) usually take place by persistent westerlies in Northeast Asia. The hourly GOCI-retrieved AOD with high spatial resolution of $500 \mathrm{~m} \times 500 \mathrm{~m}$ was provided in order to improve the accuracy of the CMAQ-simulated AOD through data assimilation, which produced a two-dimensional set of AOD data over the modeling domain. Using the assimilated AOD data, the LRT and the non-LRT events were distinguished, and the impact of the LRT events were estimated. During the LRT events, the average AOD increases of 117-265\% were found at the five AERONET sites in Korea and Japan compared to the average background AOD value. In addition, the average AOD increase of $121 \%$ over the entire Korean peninsula was also estimated. This strongly indicates that the noticeable amounts of particulate matter emitted from/formed in China were transported into the Korean peninsula through the LRT processes.

The analysis framework presented here that utilizes new GOCI retrievals of AOD provides a powerful means to better document and estimate the contributions of LRT to PM 
(a)

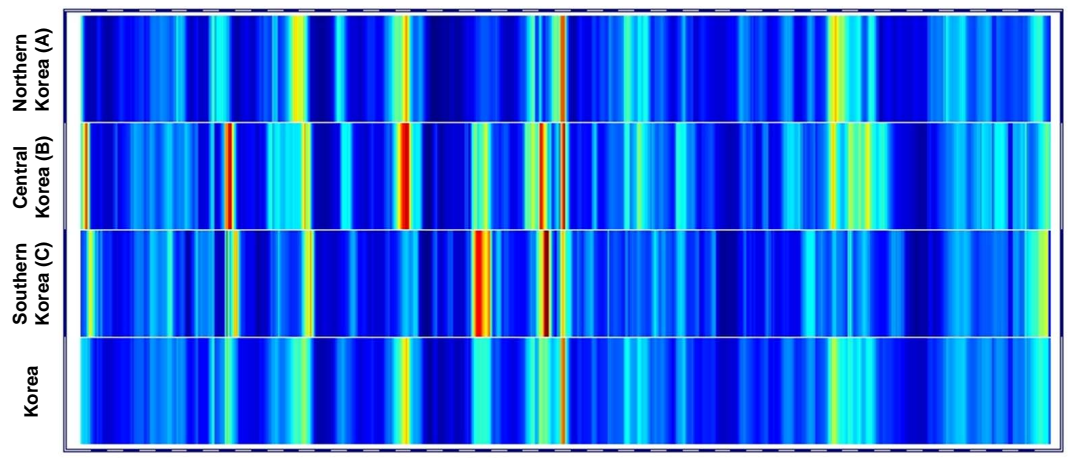

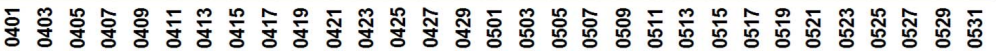

(b)

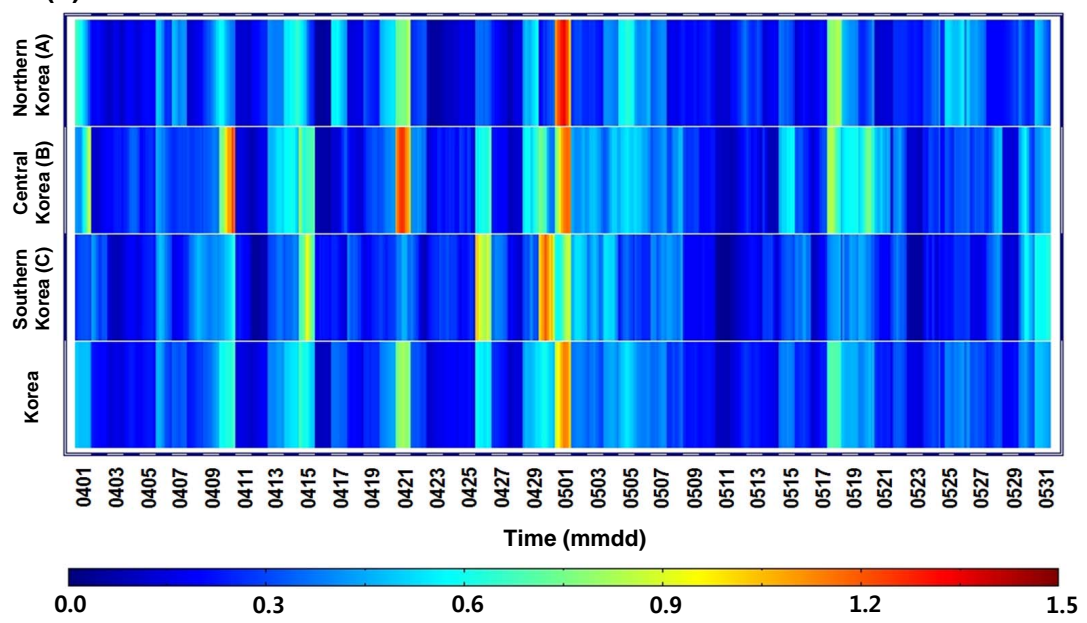

Fig. 9. Time series plots of daily and regionally averaged AODs, based on AOD products calculated via Chin et al.'s (2002) algorithm (a) and Park et al.'s (2011) algorithm (b) over northern Korea (A), central Korea (B), southern Korea (C), and the entire Korean peninsula, shown in Fig. 1, for the modeling period of 1 April to 31 May 2011.

pollution. This has important policy implications. AOD retrievals from geostationary platforms greatly increase the amount of observations that go into such estimates and greatly reduce the uncertainties that a model adds to the analysis. With higher confidence and accuracy in the estimates it is easier for policy makers to discuss transboundary PM pollution over a region like Northeast Asia. Looking forward, new observation systems are being designed that will provide more comprehensive aerosol information. For example, the Korean GEMS and the second version of GOCI (GOCI-2) sensors are scheduled to be launched in 2018. GEMS will become the world's first geostationary environmental monitoring sensor that will be able to provide approximately 10 snapshots per day of information on air pollutants over China, Korea, Japan, Southeast Asia, and parts of India, Russia, and Central Asia, with a grid resolution of $5 \mathrm{~km} \times 5 \mathrm{~km}$. GEMS will be equipped with visible and UV channels. Thus, aerosol optical properties (e.g., AOD) as well as gas data (e.g., tro- pospheric $\mathrm{NO}_{2}, \mathrm{SO}_{2}, \mathrm{O}_{3}, \mathrm{CH}_{2} \mathrm{O}$, and glyoxal) will also be retrieved.

GOCI-2 will again monitor the ocean colors over a similar domain as GOCI-1, but with 13 visible/NIR channels and a smaller grid resolution of $0.25 \mathrm{~km} \times 0.25 \mathrm{~km}(\mathrm{Ahn}$, 2009). Together with smaller grid resolution of GOCI-2, the retrieval algorithm of AOPs from the geostationary satellite sensors such as GOCI, GOCI-2, and GEMS will be further developed in order to overcome the limitations of the current algorithms. For example, as discussed in Sect. 3.1, the current retrieval algorithm cannot perfectly screen out thin clouds. These limitations and possible errors will/should be overcome in the future works. In addition, the AOD distributions obtained by applying the methodology discussed in this paper with the GEMS and GOCI-2 data will be greatly improved. In addition to the data sets that will be retrieved from the upcoming satellite sensors (GEMS and GOCI-2), the MET and CTM simulations together with the emissions of air pollutants in East/Northeast Asia will/should 
also be improved continuously in order to produce more accurate AOP distributions. Better AOP distributions will also be generated if a better data assimilation technique, such as ensemble Kalman filter method, is utilized in the future applications. Ultimately, the GEO satellite sensor-derived hourly production of more accurate AOPs together with other pollutant information over East/Northeast Asia is expected to greatly improve our ability to predict and to investigate air quality and climate forcing in East/Northeast Asia in the future.

\section{Appendix A}

Over the ocean areas, aerosol retrieval process is hindered over sun-glint regions where strong specular reflection occurs. The sun-glint region is determined by the glint angle less than or equal to $40^{\circ}$ in both GOCI and MODIS algorithms, where the glint angle is defined by

$$
\text { Glint angle }=\cos ^{-1}\left(\cos \theta \cos \theta^{\circ}+\sin \theta \sin \theta^{\circ} \cos \psi\right),
$$

where $\theta^{\circ}$ is the solar zenith angle, $\theta$ is the viewing zenith angle, and $\psi$ is the relative azimuth angle. Since the sun-glint occurs in the specular reflection direction, a larger area is under the effect of sun-glint for cross-track scanning sensors in sun-synchronous orbits, such as MODIS rather than sensors in geostationary orbits.

Acknowledgements. This work was funded by the Eco-Innovation project 2012000160004 from the Korean Ministry of Environment, and the Korea Meteorological Administration Research and Development Program under grant CATER 2012-7110. The authors express special thanks to the GOCI science team at Korea Institute of Ocean Science and Technology (KIOST) and the Korea Aerospace Research Institute (KARI) for their innovative contributions to implement the mission successfully.

Edited by: A. B. Guenther

\section{References}

Adhikary, B., Kulkarni, S., Dallura, A., Tang, Y., Chai, T., Leung, L. R., Qian, Y., Chung, C. E., Ramanathan, V., and Carmichael, G. R.: A regional scale chemical transport modeling of Asian aerosols with data assimilation of AOD observations using optimal interpolation technique, Atmos. Environ., 42, 8600-8615, 2008.

Ahn, Y.-H.: Present status of GOCI/COMS and GOCI-2, IOCCG14 meeting, http://www.ioccg.org/sensors/AHN-Revised_ 2009-ver_3.pdf (last access: 18 January 2014), 2009.

Al-Saadi, J., Szykman, J., Pierce, R. B., Kittaka, C., Neil, D., Chu, D. A., Remer, L., Gumley, L., Prins, E., Weinstock, L., MacDonald, C., Wayland, R., Dimmick, F., and Fishman, J.: Improving national air quality forecasts with satellite aerosol observations, B. Am. Meteorol. Soc., 86, 1249-1261, 2005.
Arndt, R. L., Carmichael, G. R., and Roorda, J. M.: Seasonal source-receptor relationships in Asia, Atmos. Environ., 32, 1397-1406, 1998.

Brankov, E., Henry, R. F., Civerolo, K. L., Hao, W., Rao, S. T., Misra, P. K., Bloxam, R., and Reid, N.: Assessing the effects of transboundary ozone pollution between Ontario, Canada and New York, USA, Environ. Pollut., 123, 403-411, 2003.

Byun, D. W. and Schere, K. L.: Review of the governing equations, computational algorithm, and other components of the Models-3 Community Multi-scale Air Quality (CMAQ) Modeling system, Appl. Mech. Rev., 59, 51-77, 2006.

Chin, M., Ginoux, P., Kinne, S., Torres, O., Holben, B. N., Duncan, B. N., Martin, R. V., Logan, J. A., Higurashi, A., and Nakajima, T.: Tropospheric aerosol optical thickness from the GOCART model and comparisons with satellite and sun photometer measurements, J. Atmos. Sci., 59, 461-483, 2002.

Chin, M., Chu, A., Levy, R., Remer, L., Kaufman, Y., Holben, B. N., Eck, T. F., Ginoux, P., and Gao, O.: Aerosol distribution in the Northern Hemisphere during ACE-Asia: Results from global model, satellite observations, and Sun photometer measurements, J. Geophys. Res., 109, D23S90, doi:10.1029/2004JD004829, 2004.

Choi, Y.-S., Park, R. J., and Ho, C.-H.: Estimates of ground-level aerosol mass concentrations using a chemical transport model with Moderate Resolution Imaging Spectroradiometer (MODIS) aerosol observations over East Asia, J. Geophys. Res., 114, D04204, doi:10.1029/2008JD011041, 2009.

Christopher, S. A., Zhang, J., Holben, B. N., and Yang, S.-K.: GOES-8 and NOAA-14 AVHRR retrieval of smoke aerosol optical thickness during SCAR-B, Int. J. Remote Sens., 23, 49314944, 2002.

Chung, C. E., Ramanathan, V., Carmichael, G., Kulkarni, S., Tang, Y., Adhikary, B., Leung, L. R., and Qian, Y.: Anthropogenic aerosol radiative forcing in Asia derived from regional models with atmospheric and aerosol data assimilation, Atmos. Chem. Phys., 10, 6007-6024, doi:10.5194/acp-10-6007-2010, 2010.

Collins, W. D., Rasch, P. J., Eaton, B. E., Khattatov, B. V., and Lamarque, J.-F.: Simulating aerosols using a chemical transport model with assimilation of satellite aerosol retrievals: Methodology for INDOEX, J. Geophys. Res., 106, 7313-7336, 2001.

d'Almeida, G. A., Koepke, P., and Shettle, E. P.: Atmospheric aerosols: global climatology and radiative characteristics, A. Deepak Publishing, Hampton, Virginia, USA, 1991.

Daum, P. H., Kleinman, L. I., Newman, L., Luke, W. T., WeinsteinLloyd, J., Berkowitz, C. M., and Busness, K. M.: Chemical and physical properties of plumes of anthropogenic pollutants transported over the North Atlantic during the North Atlantic Regional Experiment, J. Geophys. Res., 101, 29029-29042, 1996.

Diner, D. J., Abdou, W. A., Bruegge, C. J., Conel, J. E., Crean, K. A., Gaitley, B. J., Helmlinger, M. C., Kahn, R. A., Martonchik, J. V., Pilorz, S. H., and Holben, B. N.: MISR aerosol optical depth retrievals over southern Africa during the SAFARI-2000 dry season campaign, Geophys. Res. Lett., 28, 3127-3130, 2001.

Draxler, R. R. and Hess, G. D.: An overview of the HYSPLIT4 modeling system for trajectories, dispersion, and deposition, Aust. Meteorol. Mag., 17, 295-308, 1998.

Dubovik, O., Smirnov, A., Holben, B. N., King, M. D., Kaufman, Y. J., Eck, T. F., and Slutsker, I.: Accuracy assessments of aerosol optical properties retrieved from Aerosol Robotic Net- 
work (AERONET) Sun and sky radiance measurements, J. Geophys. Res., 105, 9791-9806, 2000.

Eck, T. F., Holben, B. N., Reid, J. S., Dubovik, O., Smirnov, A., O'Neill, N. T., Slutsker, I., and Kinne, S.: Wavelength dependence of the optical depth of biomass burning, urban, and desert dust aerosols, J. Geophys. Res., 104, 31333-31349, 1999.

Engel-Cox, J. A., Holloman, C. H., Coutant, B. W., and Hoff, R. M.: Qualitative and quantitative evaluation of MODIS satellite sensor data for regional and urban scale air quality, Atmos. Environ., 38, 2495-2509, 2004.

Grell, G. A., Dudhia, J., and Stauffer, D. R.: A description of the fifth-generation Penn State/NCAR Mesoscale Model (MM5), NCAR Tech. Note NCAR/TN-398+STR, 1-122, 1995.

Hess, M., Koepke, P., and Schult, I.: Optical properties of aerosols and clouds: the software package OPAC, B. Am. Meteorol. Soc., 79, 831-844, 1998.

Holben, B. N., Eck, T. F., Slutsker, I., Tanré, D., Buis, J. P., Setzer, A., Vermote, E., Reagan, J. A., Kaufman, Y. J., Nakajima, T., Lavenu, F., Jankowiak, I., and Smirnov, A.: AERONET - A federated instrument network and data archive for aerosol characterization, Remote Sens. Environ., 66, 1-16, 1998.

Holloway, T., Levy II, H., and Carmichael, G. R.: Transfer of reactive nitrogen in Asia: development and evaluation of a sourcereceptor model, Atmos. Environ., 36, 4251-4264, 2002.

Holloway, T., Fiore, A., and Hastings, M. G.: Intercontinental transport of air pollution: will emerging science lead to a new hemispheric treaty?, Environ. Sci. Technol., 37, 4535-4542, 2003.

Kaufman, Y. J., Tanré, D., Remer, L. A., Vermote, E. F., Chu, A., and Holben, B. N.: Operational remote sensing of tropospheric aerosol over land from EOS moderate resolution imaging spectroradiometer, J. Geophys. Res., 102, 17051-17067, 1997.

Kim, J., Lee, J., Lee, H. C., Higurashi, A., Takemura, T., and Song, C. H.: Consistency of the aerosol type classification from satellite remote sensing during the Atmospheric Brown Cloud-East Asia Regional Experiment campaign, J. Geophys. Res., 112, D22S33, doi:10.1029/2006JD008201, 2007.

Kim, J., Yoon, J.-M., Ahn, M. H., Sohn, B. J., and Lim, H. S.: Retrieving aerosol optical depth using visible and mid-IR channels from geostationary satellite MTSAT-1R, Int. J. Remote Sens., 29, 6181-6192, 2008.

Kim, S.-B., Yumimoto, K., Uno, I., and Chun, Y.: Dust model intercomparison between ADAM and CFORS/Dust for Asian dust case in 2007 (28 March-3 April), SOLA, 7A, 025-028, 2011.

Knapp, K. R., Vonder Haar, T. H., and Kaufman, Y. J.: Aerosol optical depth retrieval from GOES-8: Uncertainty study and retrieval validation over South America, J. Geophys. Res., 107, 4055, doi:10.1029/2001JD000505, 2002.

Knapp, K. P., Frouin, R., Kondragunta, S., and Prados, A.: Toward aerosol optical depth retrievals over land from GOES visible radiances: determining surface reflectance, Int. J. Remote Sens., 26, 4097-4116, 2005.

Laszlo, I., Ciren, P., Liu, H., Kondragunta, S., Tarpley, J. D., and Goldberg, M. D.: Remote sensing of aerosol and radiation from geostationary satellites, Adv. Space Res., 41, 1882-1893, 2008.

Lee, J., Kim, J., Song, C. H., Ryu, J.-H., Ahn, Y.-H., and Song, C. K.: Algorithm for retrieval of aerosol optical properties over the ocean from the Geostationary Ocean Color Imager, Remote Sens. Environ., 114, 1077-1088, doi:10.1016/j.rse.2009.12.021, 2010.
Lee, J., Kim, J., Yang, P., and Hsu, N. C.: Improvement of aerosol optical depth retrieval from MODIS spectral reflectance over the global ocean using new aerosol models archived from AERONET inversion data and tri-axial ellipsoidal dust database, Atmos. Chem. Phys., 12, 7087-7102, doi:10.5194/acp-12-70872012, 2012.

Levy II, H. and Moxim, W. J.: Fate of US and Canadian combustion nitrogen emissions, Nature, 328, 414-416, 1987.

Liu, Y., Park, R. J., Jacob, D. J., Li, Q. B., Kilaru, V. and Sarnat, J. A.: Mapping annual mean ground-level $\mathrm{PM}_{2.5}$ concentrations using multiangle imaging spectroradiometer aerosol optical thickness over the contiguous United States, J. Geophys. Res., 109, D22206, doi:10.1029/2004JD005025, 2004.

Liu, Y., Sarnat, J. A., Kilaru, V., Jacob, D. J., and Koutrakis, P.: Estimating ground-level $\mathrm{PM}_{2.5}$ in the eastern United States using satellite remote sensing, Environ. Sci. Technol., 39, 3269-3278, 2005.

Malcolm, A. L., Derwent, R. G., and Maryon, R. H.: Modelling the long-range transport of secondary $\mathrm{PM}_{10}$ to the UK, Atmos. Environ., 34, 881-894, 2000.

Malm, W. C., Sisler, J. F., Huffman, D., Eldred, R. A., and Cahill, T. A.: Spatial and seasonal trends in particle concentration and optical extinction in the United States, J. Geophys. Res., 99, 13471370, 1994.

Malm, W. C. and Hand, J. L.: An examination of the physical and optical properties of aerosols collected in the IMPROVE program, Atmos. Environ., 41, 3407-3427, 2007.

Masuda, K., Mano, Y., Ishimoto, H., Tokuno, M., Yoshizaki, Y., and Okawara, N.: Assessment of the nonsphericity of mineral dust from geostationary satellite measurements, Remote Sens. Environ., 82, 238-247, 2002.

Müller, J.-F., Stavrakou, T., Wallens, S., De Smedt, I., Van Roozendael, M., Potosnak, M. J., Rinne, J., Munger, B., Goldstein, A., and Guenther, A. B.: Global isoprene emissions estimated using MEGAN, ECMWF analyses and a detailed canopy environment model, Atmos. Chem. Phys., 8, 1329-1341, doi:10.5194/acp-81329-2008, 2008

Park, R. J., Jacob, D. J., Field, B. D., Yantosca, R. M., and Chin, M.: Natural and transboundary pollution influences on sulfate-nitrate-ammonium aerosols in the United States: Implications for policy, J. Geophys. Res., 109, D15204, doi:10.1029/2003JD004473, 2004.

Park, R. S., Song, C. H., Han, K. M., Park, M. E., Lee, S.-S., Kim, S.-B., and Shimizu, A.: A study on the aerosol optical properties over East Asia using a combination of CMAQ-simulated aerosol optical properties and remote-sensing data via a data assimilation technique, Atmos. Chem. Phys., 11, 12275-12296, doi:10.5194/acp-11-12275-2011, 2011.

Park, S.-U. and Lee, E.-H.: Parameterization of Asian dust (Hwangsa) particle-size distributions for use in dust emission models, Atmos. Environ., 38, 2155-2162, 2004.

Popp, C., Hauser, A., Foppa, N., and Wunderle, S.: Remote sensing of aerosol optical depth over central Europe from MSG-SEVIRI data and accuracy assessment with ground-based AERONET measurements, J. Geophys. Res., 112, D24S11, doi:10.1029/2007JD008423, 2007.

Rajeev, K., Ramanathan, V., and Meywerk, J.: Regional aerosol distribution and its long-range transport over the Indian Ocean, J. Geophys. Res., 105, 2029-2043, 2000. 
Robinson, A. L., Donahue, N. M., Shrivastava, M. K., Weitkamp, E. A., Sage, A. M., Grieshop, A. P., Lane, T. E., Pierce, J. R., and Pandis, S. N.: Rethinking organic aerosols: semivolatile emissions and photochemical aging, Science, 315, 1259-1262, 2007.

Schaap, M., Apituley, A., Timmermans, R. M. A., Koelemeijer, R. B. A., and de Leeuw, G.: Exploring the relation between aerosol optical depth and $\mathrm{PM}_{2.5}$ at Cabauw, the Netherlands, Atmos. Chem. Phys., 9, 909-925, doi:10.5194/acp-9-909-2009, 2009.

Schaub, D., Weiss, A. K., Kaiser, J. W., Petritoli, A., Richter, A., Buchmann, B., and Burrows, J. P.: A transboundary transport episode of nitrogen dioxide as observed from GOME and its impact in the Alpine region, Atmos. Chem. Phys., 5, 23-37, doi:10.5194/acp-5-23-2005, 2005.

Song, C. H. and Carmichael, G. R.: A three dimensional modeling investigation of the evolution processes of dust and sea-salt particles in East Asia, J. Geophys. Res., 106, 18131-18154, 2001.

Song, C. H., Maxwell-Meier, K., Weber, R. J., Kapustin, V., and Clarke, A.: Dust composition and mixing state inferred from airborne composition measurements during ACE-Asia C130 Flight\#6, Atmos. Environ., 39, 359-369, 2005.

Song, C. H., Han, K. M., Cho, H. J., Kim, J., Carmichael, G. R., Kurata, G., Thongboonchoo, N., He, Z., and Kim, H. S.: A Lagrangian model investigation of chemico-microphysical evolution of northeast Asian pollution plumes within the MBL during TRACE-P, Atmos. Environ., 41, 8932-8951, 2007.

Song, C. H., Park, M. E., Lee, K. H., Ahn, H. J., Lee, Y., Kim, J. Y., Han, K. M., Kim, J., Ghim, Y. S., and Kim, Y. J.: An investigation into seasonal and regional aerosol characteristics in East Asia using model-predicted and remotely-sensed aerosol properties, Atmos. Chem. Phys., 8, 6627-6654, doi:10.5194/acp-8-6627-2008, 2008.

Tsai, T.-C., Jeng, Y.-J., Chu, D. A., Chen, J.-P., and Chang, S.C.: Analysis of the relationship between MODIS aerosol optical depth and particulate matter from 2006 to 2008, Atmos. Environ., 45, 4777-4788, 2011.

Tulet, P., Crassier, V., Solmon, F., Guedalia, D., and Rosset, R.: Description of the Mesoscale Non-hydrostatic chemistry model and application to a transboundary pollution episode between northern France and southern England, J. Geophys. Res., 108, 4021, doi:10.1029/2000JD000301, 2003. van Donkelaar, A., Martin, R. V., and Park, R. J.: Estimating ground-level $\mathrm{PM}_{2.5}$ using aerosol optical depth determined from satellite remote sensing, J. Geophys. Res., 111, D21201, doi:10.1029/2005JD006996, 2006.

Volkamer, R., Jimenez, J. L., San Martini, F., Dzepina, K., Zhang, Q., Salcedo, D., Molina, L. T., Worsnop, D. R., and Molina, M. J.: Secondary organic aerosol formation from anthropogenic air pollution: Rapid and higher than expected, Geophys. Res. Lett., 33, L17811, doi:10.1029/2006GL026899, 2006.

Wang, J. and Christopher, S. A.: Intercomparison between satellitederived aerosol optical thickness and $\mathrm{PM}_{2.5}$ mass: Implications for air quality studies, Geophys. Res. Lett., 30, 2095, doi:10.1029/2003GL018174, 2003.

Wang, J., Christopher, S. A., Brechtel, F., Kim, J., Schmid, B., Redemann, J., Russell, P. B., Quinn, P., and Holben, B. N.: Geostationary satellite retrievals of aerosol optical thickness during ACE-Asia, J. Geophys. Res., 108, 8657, doi:10.1029/2003JD003580, 2003.

Wang, H., Jacob, D. J., Le Sager, P., Streets, D. G., Park, R. J., Gilliland, A. B., and van Donkelaar, A.: Surface ozone background in the United States: Canadian and Mexican pollution influences, Atmos. Environ., 43, 1310-1319, 2009.

Wiedinmyer, C., Akagi, S. K., Yokelson, R. J., Emmons, L. K., AlSaadi, J. A., Orlando, J. J., and Soja, A. J.: The Fire INventory from NCAR (FINN): a high resolution global model to estimate the emissions from open burning, Geosci. Model Dev., 4, 625641, doi:10.5194/gmd-4-625-2011, 2011.

Yamaji, K., Uno, I., and Irie, H.: Investigating the response of East Asian ozone to Chinese emission changes using a linear approach, Atmos. Environ., 55, 475-482, 2012.

Yu, H., Dickinson, R. E., Chin, M., Kaufman, Y. J., Holben, B. N., Geogdzhayev, I. V., and Mishchenko, M. I.: Annual cycle of global distributions of aerosol optical depth from integration of MODIS retrievals and GOCART model simulations, J. Geophys. Res., 108, 4128, doi:10.1029/2002JD002717, 2003.

Yumimoto, K. and Takemura, T.: Direct radiative effect of aerosols estimated using ensemble-based data assimilation in a global aerosol climate model, Geophys. Res. Lett., 38, L21802, doi:10.1029/2011GL049258, 2011. 